Chapter 14

\title{
Soybean in Monogastric Nutrition: Modifications to Add Value and Disease Prevention Properties
}

\author{
Samuel N. Nahashon and \\ Agnes K. Kilonzo-Nthenge \\ Additional information is available at the end of the chapter \\ http://dx.doi.org/10.5772/52991
}

\section{Introduction}

Soybean (Glycine max), a leguminous oilseed and one of the world's largest and most efficient sources of plant protein, has on average crude protein content of about $37-38 \%$ and $20 \%$ fat on a dry matter basis. The crude protein content of soybean varies with geographical region and damage to the soybean crop can cause a significant decrease in the crude protein content of the soybean. On the other hand, processed soybean meal which is commonly used in monogastric feeding contains about $44-48 \%$ crude protein (NRC, 1998). This high crude protein content of soybean and soybean meal in conjunction with high energy due to significant fat content and low fiber content make soybean an ideal source of protein for humans and also ideal feed ingredient in monogastric animals feeding (Table 1). The heat processed soybean is the form primarily used for human consumption and it contains lower crude protein concentration (37\%) when compared to soybean meal which is produced from solvent extracted seeds and seeds without hulls ( $44 \%$ and $49 \% \mathrm{CP}$, respectively). The soybean meal is the common form of soybean utilized in animal feeding. While other nutrients such as calcium, potassium and zinc also tend to be lower in heat treated soybean than in the soybean meals, the energy and fat content is higher in the heated soybean than the soybean meals.

Previous reports have shown that soybean and soybean meal contains a balanced amino acid profile when compared with other oilseed meals, although it is deficient in methionine and lysine (Zhou et al., 2005). The comparisons of the amino acid composition of soybean and soybean meal which are routinely utilized in human and monogastric feeding are presented in Table 2. 


\begin{tabular}{|c|c|c|c|}
\hline Nutrient & Soybean seeds ${ }^{2}$ & Soybean $\mathrm{Meal}^{3}$ & Soybean Meal ${ }^{4}$ \\
\hline $\mathrm{IFN}^{5}$ & $5-04-597$ & $5-04-604$ & $5-04-612$ \\
\hline Crude Protein, \% & 37 & 44 & 49 \\
\hline Energy, kcal/kg & 3,300 & 2,230 & 2,440 \\
\hline Crude fat, \% & 18 & 0.8 & 1.0 \\
\hline Crude fiber, \% & 5.5 & 7.0 & 3.9 \\
\hline Calcium, \% & 0.25 & 0.29 & 0.27 \\
\hline Phosphorus ${ }^{6}, \%$ & - & 0.65 & 0.62 \\
\hline Phosphorus 7 , \% & 0.53 & 0.27 & 0.24 \\
\hline Potassium, \% & 1.61 & 2.00 & 1.98 \\
\hline Iron, mg/kg & 80 & 120 & 170 \\
\hline Zinc, mg/kg & 25 & 40 & 55 \\
\hline
\end{tabular}

${ }^{1}$ National Research Council 1994. ${ }^{2}$ Heat processed. ${ }^{3}$ Seeds, meal solvent extracted.

${ }^{4}$ Seeds without hulls, meal solvent extracted. International feed number. ${ }^{6}$ Total phosphorus.

${ }^{7}$ Non-phytate or available phosphorus.

Table 1. Comparison of selected nutrient composition of soybean and soybean meal ${ }^{1}$

Soybean boasts a well balanced amino acid profile with high digestibility when compared with other oilseeds. In soybean, the digestibility coefficients of lysine are estimated to be 91\% (NRC, 1994) whereas that of cysteine and phenylalanine is estimated at 83-93 (Bandegan et al, 2010). Previous reports cite evidence that soya is a rich source of amino acids (Angkanaporn et al., 1996). Holle (1995) reported that soybean meal provides the best balance for amino acids when compared with other oilseeds and thus makes it a more suitable plant source protein for human and monogastric food animals. According to Kohl-Meier (1990), soybean accounts for more than $50 \%$ of the world's protein meal. The form in which soybean is utilized for human or monogastric feeding determines the nutritional value in terms of content and bioavailability of amino acids as described in the following section.

\section{Anti-nutritional properties of soybean}

In their natural form, soybeans contain anti-nutrients or phytochemicals which bear toxic effects when ingested by both humans and monogastric food animals. These anti-nutrients are nature's means of protection for the soybean plant from invasion by animals, bacteria, viruses and even fungi in the ecosystem. The major anti-nutrients in soybean are phytates, protease enzyme inhibitors, soyin, goitrogens, hemagglutinins or lectins, giotrogens, cyanogens, saponins, estrogens, antigens, non-starch polysaccharides and soy oligosaccharide. Although most of these anti-nutritional compounds in soybean were discussed in Nahashon 
and Kilonzo-Nthenge (2011), additional reviews of some of the major anti-nutritional factors are presented as follows:

\begin{tabular}{|c|c|c|c|}
\hline Nutrient & Soybean seeds ${ }^{2}$ & Soybean $\mathrm{Meal}^{3}$ & Soybean Meal ${ }^{4}$ \\
\hline \multirow[t]{2}{*}{$\mathrm{IFN}^{6}$} & $5-04-597$ & $5-04-604$ & $5-04-612$ \\
\hline & \multicolumn{3}{|c|}{ - } \\
\hline Arginine & 2.59 & 3.14 & 3.48 \\
\hline Lysine & 2.25 & 2.69 & 2.96 \\
\hline Methionine & 0.53 & 0.62 & 0.67 \\
\hline Cystine & 0.54 & 0.66 & 0.72 \\
\hline Tryptophan & 0.51 & 0.74 & 0.74 \\
\hline Histidine & 0.90 & 1.17 & 1.28 \\
\hline Leucine & 2.75 & 3.39 & 3.74 \\
\hline Isoleucine & 1.56 & 1.96 & 2.12 \\
\hline Phenylalanine & 1.78 & 2.16 & 2.34 \\
\hline Threonine & 1.41 & 1.72 & 1.87 \\
\hline Valine & 1.65 & 2.07 & 2.22 \\
\hline Glycine & 1.55 & 1.90 & 2.05 \\
\hline Serine & 1.87 & 2.29 & 2.48 \\
\hline Tyrosine & 1.34 & 1.91 & 1.95 \\
\hline \multicolumn{4}{|c|}{${ }^{1}$ National Research Council, 1994.} \\
\hline \multicolumn{4}{|l|}{2 Seeds, heat processed. } \\
\hline \multicolumn{4}{|c|}{${ }^{3}$ Seeds, meal solvent extracted. } \\
\hline \multicolumn{4}{|c|}{${ }^{4}$ Seeds without hulls, meal solvent extracted. } \\
\hline International feed $\mathrm{n}$ & & & \\
\hline
\end{tabular}

Table 2. Comparison of selected amino acid composition of soybean and Soybean meals ${ }^{1}$

\subsection{Phytates}

Phytic acid (inositol hexakisphosphate), the storage form of phosphorus in seeds such as those of soybean is considered an anti-nutritional factor in monogastric nutrition. Raboy et al. (1984) cited evidence that phytic acid accounted for $67-78 \%$ of the total phosphorus in mature soybean seeds and these seed contain about $1.4-2.3 \%$ phytic acid which varies with soybean cultivars. In plants phytic acid is the principal store of phosphate and also serves as natural plant antioxidant. Earlier reports (Asada et al., 1969) suggested that phytic acid in soybean not only makes phosphorus unavailable, but also reduces the bioavailability of other trace elements such as zinc and calcium and the digestibility of amino acids (Ravindran, 1999). Ravindran et al., (1999) reported that in the presence of phytate, soybean protein 
forms complexes with the phytate. Heaney et al. (1991) reported that the absorption of calcium from soybean-based diets was higher in low-phytate soybean when compared with high phytate-soybean. This supports the assertion that soybean has the potential to form phytatemineral-complex which inhibits the availability of the minerals to monogastric animals. In soybean, phytate is usually a mixture of calcium/magnesium/potassium salts of inositol hexaphosphoric acid which adversely affects mineral bioavailability and protein solubility when present in animal feeds (Liener, 1994). Reports of Vucenik and Shamsuddin (2003) point that inositol bears biological significance as antioxidant in mammalian cells. However, it interferes with mineral utilization and is the primary cause of low phosphorus utilization in soy-based poultry and swine diets. Phytin also chelates other minerals such as Calcium, Zinc, iron, Manganese and Copper, rendering them unavailable to the animals. Soybean has the highest amount of phytate when compared to all legumes and cereal grains. The phytates have been reported to be resistant to cooking temperatures.

\subsection{Protease enzyme inhibitors}

Proteases refer to a group of enzymes whose catalytic function is to hydrolyze, cleave or breakdown peptide bonds of proteins. They are also called proteolytic enzymes that include trypsin, chymotrypsin, elastase, carboxypeptidase, and aminopeptidase which convert protein (polypeptides, dipeptides, and tripeptides) into free amino acids which are readily absorbed through the small intestine into the blood stream. Protease or trypsin inhibitors of soybean have been reported to hinder the activity of the proteolytic enzymes trypsin and chymotrypsin in monogastric animals which in turn lowers protein digestibility (Liener and Kakade, 1980). Other reports (Liener and Kakade, 1969; Rackis, 1972) confirmed that trypsin inhibitors were key substances in soybean that adversely affected its utilization by chicks, rats and mice. Kunitz, (1946) isolated trypsin inhibitor from raw soybeans and demonstrated that it was associated with growth inhibition. These protease inhibitors were also reported to inhibit Vitamin $B_{12}$ availability (Baliga et al., 1954). Later studies have also shown that the presence of dietary soybean trypsin inhibitors caused a significant increase in pancreatic proteases (Temler et al., 1984). To the benefit of the soybean plant, soybean protease inhibitors serve as storage proteins in seeds, regulate endogenous proteinases, and also protect the plant and seeds against insect and/or microbial proteinases (Hwang et al., 1978). These protease inhibitors contain about $20 \%$ of the sulfur-containing amino acids methionine and cysteine, which are also the most limiting essential amino acids in soybean seeds (Hwang et al., 1978).

Recent reports (Dilger et al., 2004; Opapeju et al. 2006; Coca-Sinova et al. 2008) show that the nutritional value of soybean meal for monogastric animals is significantly hindered by these protease inhibitors which interfere with feed intake and nutrient metabolism. They reported that soybeans with high content protease inhibitors, especially trypsin inhibitors adversely affect protein digestibility and amino acid availability. In earlier reports, Birth et al. (1993) cited evidence that ingestion of food containing trypsin inhibitor by pigs increased endogenous nitrogen losses hence the effect of the trypsin inhibitors affected nitrogen balance more by losses of amino acids of endogenous secretion than by losses of dietary amino acids. This may be due to compromised integrity of the gastrointestinal lining leading to reduction of 
absorptive surface. However, Gertler et al. (1967) attributed the depression of protein digestibility to reduced proteolysis and absorption of the exogenous or dietary protein which was caused by inhibition of pancreatic proteases.

\subsection{Hemagglutinins or lectins}

Soybean hemagglutinins or lectins are glycoproteins that resemble some animal glycoproteins, such as ovalbumin and are rich in the acidic amino acids while being low in the sulfurcontaining amino acids methionine and cysteine. According to Lis et al. (1966), the only carbohydrates serving as constituents of soybean hemagglutinins are mannose and glucosamine. Soybean hemaglutinins are a component of soybeans that were characterized by Schulze et al. (1995) as being anti-nutritional. Oliveira et al. (1989) reported that these glycoproteins bind to cellular surfaces via specific oligosaccharides or glycopeptides. They exhibit high binding affinity to small intestinal epithelium (Pusztai, 1991) which impairs the brush border and interfere with nutrient absorption. Hemaglutinins have also been implicated in producing structural changes in the intestinal epithelium and resisting gut proteolysis (Pusztai et al., 1990), changes which in most cases result in impairment of the brush border and ulceration of villi (Oliveira et al., 1989). This occurrence result in significant decrease in the absorptive surface and increase endogenous nitrogen losses as reported by Oliveira and Sgarbierri (1986) and Schulze et al. (1995). Consequently, Pusztai et al. (1990) observed that hemagglutinins depressed growth rate in young animals. Hemagglutinins are known to promote blood clotting or facilitating clumping together of red blood cells. It has however been concluded that soybean hemagglutinins play a minor role in the deleterious effect contributed by anti-nutritional factors in raw soybean.

\subsection{Giotrogens and estrogens}

Soybean is known to produce estrogenic isoflavones which bind to the estrogen receptors. According to Doerge and Sheehan (2002), such estrogenicity was implicated in toxicity and estrogen-mediated carcinogenesis in rats. Genistein is the major soy isoflavones of great concern in conferring estrogenic effect especially in women. Although the possible gitrogenic effect of the soybean isoflavones has not been researched extensively, certain soy components may present some antithyroid actions, endocrine disruption, and carcinogenesis in animals and humans as well. Messina, (2006) reported that Soybean contains flavonoids that may impair the activity of the enzymes thyroperoxidase. Earlier reports (Divi and Doerge, 1996) indicate that plant-derived foods such as soybean contain flavonoids which are widely distributed, possessing numerous biological activities that include antithyroidism in experimental animals and humans. A study was conducted to evaluate inhibition of thyroid peroxidase (TPO), the enzyme that catalyzes thyroid hormone biosynthesis, by 13 commonly consumed flavonoids (Divi and Doerge, 1996). Consequently, most flavonoids tested including genistein and daidzein were potent inhibitors of TPO (Figure 1). They suggested that chronic consumption of flavonoids, especially suicide substrates, could play a role in the etiology of thyroid cancer. More recent reports (Messina, 2006; Xiao, 2008; Zimmermann, 2009) have also shown that use of soy-based formula without added iodine can produce goiter 
and hypothyroidism in infants, but in healthy adults soy-based products appear to have negligible adverse effects on thyroid function.

Other reports (Fort, 1990) have also shown that concentrations of soy isoflavones resulting from increased consumption of soy-based formulas inhibited thyroxine synthesis inducing goiter and hypothyroidism and autoimmune thyroid disease in infants. Still many questions linger on the full Impacts of soy products on thyroid function, reproduction and carcinogenesis, hence the need for further research in this context. According to Divi et al. (1997), the IC50 values for inhibition of TPO-catalyzed reactions by genistein and daidzein were ca. 1-10 microM, concentrations that approach the total isoflavone levels (ca. 1 microM). More recent finding using normal rats (Chang and Doerge, 2000) however suggest that, even though substantial amounts of TPO activity are lost concomitant to consumption of soy isoflavone, the remaining enzymatic activity is sufficient to maintain thyroid homeostasis in the absence of additional perturbations. On the other hand, additional factors other than the soybean isoflavones can also cause overt thyroid toxicity. These may include other soybean fractions, iodine deficiency, defects of hormone synthesis that may be caused by gene mutations or environmental and random factors including dietary factors that may be goitrogenic.

Environmental estrogens, on the other hand, are classified into two main categories namely phytoestrogens which are of plant origin and xenoestrogens which are synthetic (Dubey et al., 2000). Soybeans contain phytoestrogens which can cause enlargement of the reproductive tract disrupting reproductive efficiency in various species, including humans (Rosselli et al., 2000), and rats (Medlock et al., 1995). In some cases these estrogens are hydrolyzed in the digestive tract to form poisonous compounds such as hydrogen cyanide. Woclawek-potocka et al. (2004) reported that phytoestrogens acting as endocrine disruptors may induce various pathologies in the female reproductive tract. Studies have shown that soy-derived phytoestrogens and their metabolites disrupt reproductive efficiency and uterus function by modulating the ratio of PGF2a to PGE2. Because of the structural and functional similarities of phytoestrogens and endogenous estrogens, there is the likelihood that the plant-derived substances modulate prostaglandin synthesis in the bovine endometrium, impairing reproduction. Previous research has shown that phytoestrogens may act like antagonists or agonists of endogenous estrogens (Rosselli et al., 2000; Nejaty and Lacey, 2001).

\subsection{Allergens and antigens}

Today, food allergies are a common serious health threat and food safety concern around the world. The increasing use of soybean (Glycine max) products in processed foods owing to its nutritional and health promoting properties, poses a potential threat to individuals who allergic to foods and especially sinsitive to soybean. According to Cordle (2004), there are about 16 potential soy protein allergens that have been identified and the Food and Agriculture Organization of the United Nations includes soy in its list of the 8 most significant food allergens. While many of these soy allergenic proteins have not been fully characterized, their allergenicity can be mild to life-threatening anaphylaxis. Consequently, consumers who have allergies to soybean and soybean products are often at a risk of serious or life threatening allergic reaction if they consume these products. 


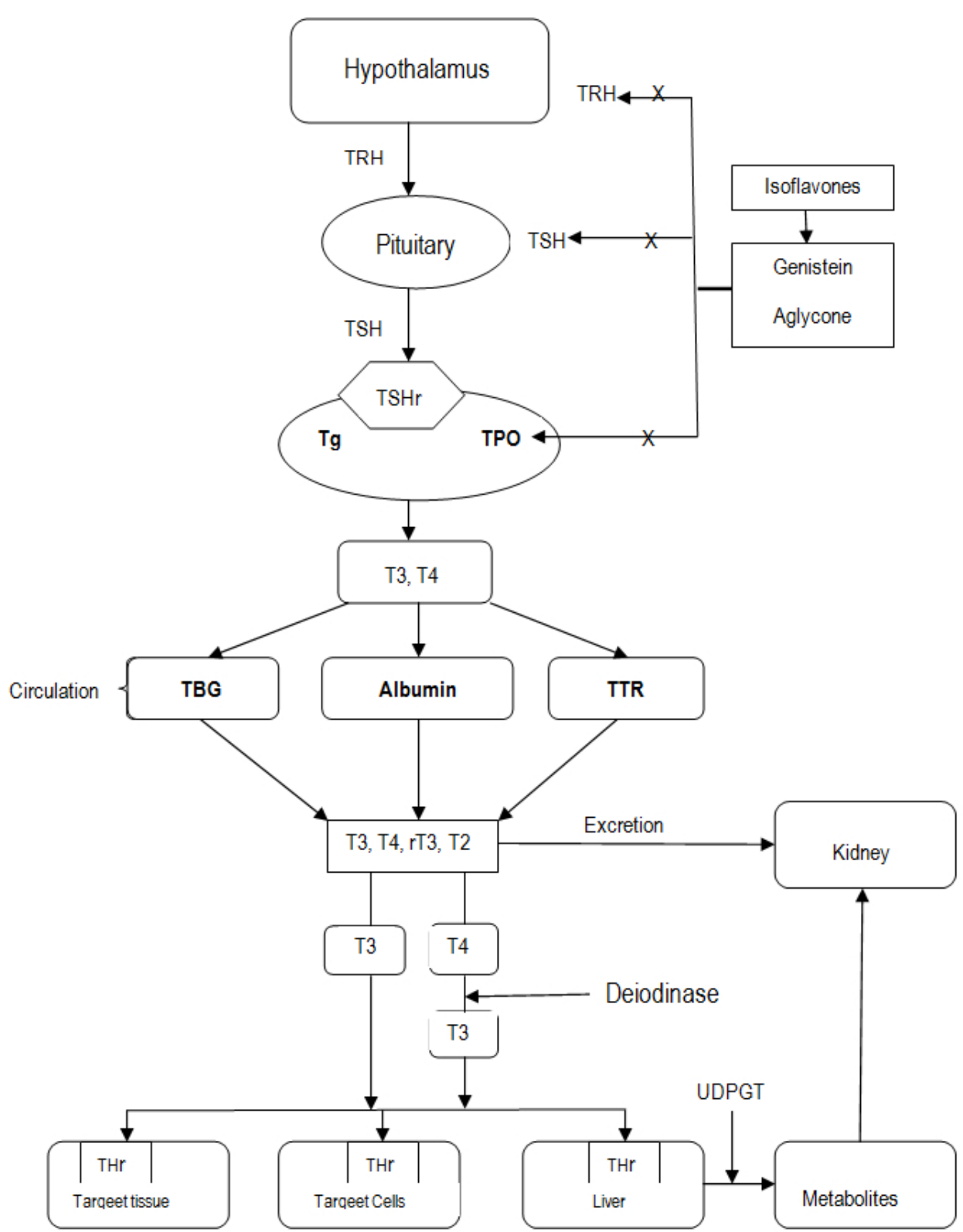

Figure 1. Schematic presentation of inhibition of TPO-catalyzed reactions by genistein and daidzein. TPO:thyroid peroxidase; UDPGT:Uridine diphosphate glucuronyltransferase; TBG:thyroxine binding globulin; TTR: Transthyretin; THr: thyroxine receptor; T:thyroxine; TSH:Thyroid stimulating hormone; TRH:Thyrotropin-releasing hormone; Tg:Thyroglobulin. 
One of these low abundance proteins, Gly m Bd $30 \mathrm{~K}$, also referred to as P34, is considered to be a dominant immunodominant soybean allergen. It is a member of the papain protease superfamily with a glycine in the conserved catalytic cysteine position found in all other cysteine proteases (Herman et al., 2003). The P34 protein is thought to trigger most allergic reactions to soy and it accumulates during seed maturation localizing in the protein storage vacuoles but not in the oil bodies (Kalinski et al., 1992). Several attempts have been made to understand and remove the allergenic proteins in soybean. Using a "gene silencing" technique, researchers were able to "knock out" a gene that makes Antigenic factors glycinin and $\beta$-conglycinin removal increases animal performance.

The prevalence of soybean allergy is estimated at $0.4 \%$ in children and $0.3 \%$ in adults North America (Sicherer and Sampson, 2010). A study was conducted to determine the relationship between adverse health outcomes and occupational risk factors among workers at a soy processing plant (Cummings et al, 2010). They reported that asthma and symptoms of asthma were associated with immune reactivity to soy dust. Such occurences are a occupational hazard and have led to strict regulatory oversight in soybean plants and food manufacturing plants that process food products containing soybean. There have been numerous recalls by the FDA (FDA Enforcement Reports) of several products containing soy proteins, paste, oils and flour for reasons ranging due to improper labeling. Unlisted soy protein on the product label is considered a potential hazard for people who may be allergic to soy.

\subsection{Cyanogens and saponins}

Soybean and other closely related legumes which are common food ingredients for human and monogastric animals have been recognized to contain cyanogenic compounds (Montgomery, 1980). The content of cyanide was reported at 0.07-0.3 pg of hydrogen cyanide/g of sample in soy protein products and $1.24 \mathrm{pg} / \mathrm{g}$ in soybean hulls when browning was kept to a minimum (Honig et al.,1983). Cyanide is considered toxic even in small amounts, hence where soy are a major constituent of a diet, there are concerns of cyanide toxicity.

On the other hand, saponins are unabsorbable glucosides of steroids, steroid alkaloids or triterpenes found in soybeans germ and cotyledons and other leguminous plants. They form lather in aqueous solutions and impart a bitter test or flavor in feed, resulting in reduction of feed consumption. In severe cases they cause haemolysis of red blood cells and diarrhea (Oakwndull, 1981). Raw soybeans have been reported to contain 2-5 g of saponins/100 g soy products. Although soybean saponins possess anti-nutritional properties, some are edible and have been reported to possess some health benefits. They have been shown to stimulate the immune system, bind to cholesterol and make it unavailable for absorption and allowing its clearance into the colon and eventual excretion (Elias et al., 1990).

\subsection{Non-starch polyssacharides and soy oligosaccharides}

Soybean oligosaccharides (OS) such as raffinose and stachyose are carbohydrates consisting of relatively small number of monosaccharides and they have been reported to influence ileal nutrient digestibility and fecal consistency in monogastric animals (Smiricky et al., 
2002). According to Leske et al., (1993), raffinose and stachyose represent about 4-6\% of soybean dry matter. The digestion of OS in the small intestine is limited because mammals lack $\alpha$-galactosidase necessary to hydrolyze the $\alpha 1,6$ linkages present in OS (Slominski, 1994). Previous research has demonstrated that soy OS are responsible for increasing intestinal viscosity of digesta and as a result interfere with digestion of nutrients by decreasing their interaction with digestive enzymes (Smits and Annison, 1996). Irish and Balnave (1993) demonstrated that stachyose derived from the oligosaccharides of soyabean meals exert anti-nutritive effects in broilers fed high concentrations soyabean meal as the sole protein concentrate. The OS in soybean, raffinose and stachyose, are not eliminated by heat treatment during processing (Leske et al., 1993). In earlier reports (Coon et al.,1990) observed that removal of the OS from SBM in poultry diets increased the true metabolizable energy value of the diet by 20 percent.

The digestion of oligosaccharides in the small and large intestine is aided by beneficial microbial fermentation (Hayakawa et al., 1990). Certain oligosaccharides, however, are considered to be prebiotic compounds because they are not hydrolyzed in the upper gastrointestinal tract and are able to favorably alter the colonic microflora, conferring beneficial effects of digestion and fermentation of carbohydrates to the host. More recent studies have demonstrated that feeding a higher level of an oligosaccharide $(8 \mathrm{~g} / \mathrm{kg})$ to chicks depressed metabolizable energy and amino acid digestibility (Biggs et al., 2007). SmirickyTjardes et al. (2003) reported the presence of significant quantities of galactooligosaccharides in soy-based swine diets. These soy oligosaccharides are partially fermented by gut microflora functioning as prebiotics which promote selective growth for beneficial bacteria. The high content of enzyme inhibitors in unfermented soybeans interferes with thecomplete digestion of carbohydrates and proteins from soybeans. When foods are not completely digested because of enzyme inhibitors, bacteria in the large intestine try to do the job, and this can cause discomfort, bloating, and embarrassment. The enzyme inhibiting properties of soybean compounds the low levels of digestive enzymes, a common phenomenon especially in elderly people.

\section{Modifications of soybean to enhance nutritional value and health benefits}

\subsection{Genetic modifications (GMO's)}

About 99 percent of the soybean that we consume is genetically modified (GMO) and referred to as GMO soybean. The genetic modifications in soybean are primarily meant to improve the yield and nutritional value of soybean, reduce allergenicity, create resistance to certain diseases or disease causing pathogens and/or confer tolerance to herbicides or adverse climatic or environmental conditions. For example, transgene-induced gene silencing was used to prevent the accumulation of Gly m Bd $30 \mathrm{~K}$ protein in soybean seeds. The Gly m Bd 30 K-silenced plants and their seeds lacked any compositional, developmental, structural, or ultrastructural phenotypic differences when compared with control plants (Herman 
et al., 2003). Current GMO crops, including soybean, have not been shown to add any additional allergenic risk beyond the intrinsic risks already present (Herman 2003).

The enhancement of the nutritional value of soybean and soybean products through genetic engineering of soybeans has been reported. Through genetic engineering completely new fatty acid biosynthetic pathways have been introduced into soybeans from exotic plants and various microorganisms (Cahoon et al., 1999; Wallis, Watts, and Browse, 2002). Soybean oil is used in many food applications and therefore alterring its composition, especially the fatty acid composition would benefit the consumer. Several fatty acids especially the omega- 3 have been reported to possess health benefit to the consumer. Engineered soybean lines that are rich in oleic acid (producing stable oil that does not need to be partially hydrogenated and is thus free of trans fatty acids) and lines lower in saturated fatty acids have been produced (Kinney \& Knowlton, 1998; Buhr et al., 2002). These high-oleic and low-saturated soybean oils provide the potential benefits to human health and point to the positive impact of the achievements in biotechnology that promote human health.

Bioactive polyunsaturated fatty acids are also known to confer beneficial and positive effects in humans' health (Knapp et al., 2003). These bioactive fatty acids can also be found in oils other than soybean can also be produced in soybean through genetic engineering. Thus, introducing these into soybean can enhance the existing health benefits of soybean with the complementary benefits of bioactive lipids and other compounds. These polyunsaturated fatty acids are known to mediate their heart-healthy effects by mechanisms independent of those of soy protein and they have been previously researched extensively (Kelley and Erikson, 2003; Knapp et al., 2003).

Previously attempts were made to increase the oxidative stability of soybean oil by increasing the composition in soybean of the fatty acids oleic and stearic and decrease linoleic acid content of the soybean without creating trans or polyunsaturated fatty acids (Clemente, 2009). According to Clemente, (2009) and Clemente and Cahoon, (2009), DuPont announced the creation of a high oleic fatty acid soybean, with levels of oleic acid greater than $80 \%$. This product was due for release into the market in 2010. Soybean mutants with elevated and reduced palmitate have been developed (Rahman et al., 1999). While the palmitate content of commercial soybean cultivars is approximately $11 \%$, elevated palmitate content in soybean oil may be important for the production of some food and industrial products.

Soy foods have also been reported (Sirtori and Lovati, 2001) to have the potential for reducing blood low-density lipoprotein (LDL) cholesterol concentrations in humans. According to Weggemans and Trautwein, (2003), this positive health effect appears to be directly related to the soy storage proteins rather than other components. The bulk of soy protein (more than $80 \%$ ) is contributed by two major classes of storage protein, conglycinin (11S globulins) and beta-conglycinin (7S globulins). It has been possible to produce soybean transgenic lines with either 7S or no 11S protein using gene-silencing techniques (Kinney \& Fader, 2002).

For many years soybean has been defined as a crop with the best amino acid composition within all cultivated protein crops and is most widely utilized for human and monogastric foods as a primary source of protein (Wenzel, 2008). Since the amino acids are directly used 
in the genetic formation of proteins and fatty acids, this makes the soybean invaluable in oil production and primary protein source of choice to many. There has been attempt through genetic engineering to modifiy the soybean to enhance its oxidative stability by changing the proportion of certain fatty acids, which would provide a more useful and abundant oil supply with health benefits to the consumer. The enhancement of soybean oil content, Clemente et al. (2009) achieved this goal by introducing a seed-specific transgene for a DGAT2-type enzyme from the oil-accumulating fungus Umbelopsis ramanniana into soybean. Without disrupting the protein content, the oil content was increased from approximately $20 \%$ of the seed weight to approximately $21.5 \%$.

There has also been an attempt to genetically modify soybean to enhance flavors. These compounds are associated with the oxidation of the polyunsaturated fatty acids linoleic and linolenic acids (Frankel, 1987). There are hundreds of volatile compounds associated with bad flavors in soy preparations (Stephan and Steinhart, 1999), and these compounds are the predominant fatty acids in soybean oil whose oxidation during bean storage and processing results in the formation of secondary products of lipid oxidation that impart off-flavors to soy protein products.

Drought tolerant varieties of soybean have also been developed through genetic engineering. The Roundup Ready soybean, also known as soybean 40-3-2, is a transgenic soybean that has been immunized to the Roundup herbicide. Although soybean's natural trypsin inhibitors provide protection against pests, weeds still remain a major challenge in soy farming (Wenzel, 2008). An herbicide used to control weeds in soybean farming contained glyphosate which inhibited the expression of the soybean plant's ESPSP gene. According to Wenzel, (2008), the gene is involved in the maintenance of the "biosynthesis of aromatic metabolites," and killed the plant along with the weeds for which the herbicide was meant. Consequently, the soybean was genetically engineered by transferring a plasmid which provided immunity to glyphosate-containing herbicides was transferred to the soybean cells through the cauliflower mosaic virus, perfecting the Roundup Ready soybean.

Since drought stress is a major constraint to the production and yield stability of soybean, integrated approaches using molecular breeding and genetic engineering have also provided new opportunities for developing high yield and drought resistance in soybeans (Manavalan et al., 2009). Recently, Yang et al. (2010) pointed out that genetic engineering must be employed to exploit yield potential and maintaining yield stability of soybean production in water-limited environments in order to guarantee the supply of food for the growing human population and for food animals. On the other hand, new soybean varieties that are resistant to diseases and pests are being developed. Hoffman et al. (1999) observed that plants commonly respond to pathogen infection by increasing ethylene production. They suggested that soybean can be altered by genetic manipulation using mutagenesis to generate soybean lines with reduced sensitivity to ethylene. Two new genetic loci were identified, Etr1 and Etr2 and Plant lines with reduced ethylene sensitivity developed similar or less-severe disease symptoms in response to virulent Pseudomonas syringae. Other reports (Yi et al., 2004) indicate that CaPF1, a ERF/AP2 transcription factor in hot pepper plants may play du- 
al roles in response to biotic and abiotic stress in plants and that through genetic engineering this factor could be modified to improve soybean disease resistance as well.

\subsection{Enzyme supplementation}

The diets of monogastric animals are primarily composed of feed ingredients of plant origin such as soybean. Soybean contains a variety of antinutritional factors such as phytin, nonstarch polysaccharides, and protease inhibitors which limit the availability of nutrients that are essential for normal growth and performance, production or otherwise. Enzyme supplementation and soybean fermentation products have been used for a long time to improve the nutritional value and health-promoting properties of soybean (Kim et al., 1999). Recent reports (Kim et al., 2010) cite evidence that fermented soybean meal can effectively serve as an alternative protein source for nursery pigs at 3-7 weeks of age, possibly replacing the use of dried skim milk which tends to be more digestible than soybean. Feng et al. (2007) evaluated the effect of soybean meal fermented with Aspergillus oryzae on the activity of digestive enzymes and intestinal morphology of broilers. The fermentation had no significant influence on the activity of lipase, amylase and protease enzymes. However, they observed a significant increase in duodenal villus height and a decrease in crypts depth a sign of improved morphology of the absorptive surface. Earlier studies by Kiers et al. (2003) indicated that fermentation of soybean resulted in an increase nutrient solubility and digestibility in broilers.

The availability of phosphorus in soybean is about 30 percent; hence diets of monogastric animals must be supplemented with inorganic phosphorus or supplemented with the phytase enzyme to improve the utilization of phytate phosphorus (NRC, 1994; Richter, 1994). Phytase (myo-inositol-hexakisphosphate phosphohydrolase) is an enzyme that catalyzes the hydrolysis of phytic acid, an indigestible inorganic form of phosphorus in oil seeds such as soybean. As a result, phytases increase the digestion of phosphorus, consequently increasing its utilization and reducing its excretion by monogastric animals. The phytase enzymes commonly used in monogastric animal feeding are derived from yeast or fungi and bacteria. Nahashon et al. (1993) reported that phosphorus retention was improved in layers when the diet was supplemented with Lactobacillus bearing phytase activity. The use of phytase to hydrolyze phosphorus and possibly other mineral elements that may be bound onto phytate such as calcium, zinc, copper, manganese and ion, has been reported (Selle and Ravindran, 2007; Powell et al., 2011).

Recently, Liu et al. (2007) demonstrated that phytase supplementation in soybean-based diets significantly improved the digestibility of phosphorus and Calcium by 11.08 and $9.81 \%$, respectively. A 2- $8 \%$ improvement of the digestibility of amino acids was also noted since phytate also binds to protein forming phytate-protein complex. This complex is less soluble resulting in decreased digestibility of soybean protein (Carnovale et al., 1988). Earlier, Singh and Kirkorian (1982) reported that phytate also inhibits trypsin and pepsin activities. These findings suggest that phytase supplementation in soybean-based diets can improve the digestibility of calcium, phosphorus and proteins and indeed amino acids. Augspurger and Baker, (2004) observed that high dietary levels of efficacious phytase enzymes can release most of the $\mathrm{P}$ from phytate, but they do not necessarily improve protein utilization (Boling- 
Frankenbach et al., 2001). Supplemental phytase has also been reported to improving dietary phosphorus utilization by pigs (Sands et al., 2001; Traylor et al., 2001). Other reports (Pillai et al., 2006) demonstrated that addition of E. coli phytase to P-deficient broiler diets improved growth, bone, and carcass characteristics. Most recently Rutherford et al. (2012) demonstrated that addition of microbial phytase to diets of broiler chickens improved significantly the availability of phytate phosphorus, total phosphorus, other minerals such as calcium, zinc, manganese etc. and amino acids.

Protease enzymes on the other hand break down long protein chains into short peptides which can be readily absorbed. These proteolytic enzymes whose catalytic function is to hydrolyze or breakdown peptide bonds of proteins include enzymes such as trypsin, chymotrypsin, pepsin, papain, elastase, plasmin, thrombin, and proteinase $\mathrm{K}$. These enzymes can also be supplemented in feed or indirectly by feeding microbials that have the potential to produce these enzymes in the gastrointestinal tract of the host animals. On the other hand, carbohydrases such as xylanase and amylase are enzymes that catalyze the hydrolysis of carbohydrates into sugars which are readily available or metabolizable by monogastric animals. Soybean meal contains approximately $3 \%$ of soluble non-starch polysaccharides (NSP) and $16 \%$ of insoluble NSP (Irish and Balnave, 1993). The NSP in soybean is thus of negligible amounts to yield digesta viscosity problems. Therefore, diets that comprise soybean are considered to be highly digestible, hence requiring less use of carbohydrases. Previous reports have, however, pointed out that since these cereal grains contain some soluble NSP, there is still the need to supplement soybean based diets with these enzymes to further improve their nutritional value (Maisonnier-Grenier et al., 2004).

Supplementing soybean based diets with multicarbohydrase enzymes, a preparation containing nonstarch polysaccharide-degrading enzymes, phytases and proteases reveled that these enzymes improved nutrient utilization and growth performance of broiler chickens (Woyengo et al., 2010). Cowieson and Ravindran (2008) reported that when these enzyme combinations were fed in broler diets with both adequate and reduced energy and amino acid content, a $3 \%$ and $11 \%$ increase in apparent metabolizable energy and nitrogen retention, respectively, were observed. Also feeding other multicarbohydrase combinations containing xylanase, protease, and amylase resulted in significant improvements in feed conversion and body weight gain of broilers (Cowieson, 2005). In their recent review, Adeola and Cowieson (2011) suggested that when used together with phytase, nonstarch polysaccharide-hydrolyzing enzymes may increase the accessibility of phytase to phytin encapsulated in plant cell walls.

Although the enhancement of monogastric animal performance using enzyme supplements in feed have been extensively researched and documented, the benefits of enzymes such as the phytases and multicarbohydrase in soybean-based diets of monogastric animals have not been fully explored and require further research. There is still a great deal of uncertainty regarding the mode of action of these enzymes including the phytases, carbohydrases and proteases and their combination thereof in soybean based diets of monogastric animals. It is just fair to not that the future of enzymes in nonruminant animal production is promising and will require further research to elucidate the role of enzyme supplementation in pro- 
moting health and provide an understanding of the modes of action of these enzymes in modulating gene functions and their interactions thereof.

\subsection{Probiotics and prebiotics supplementation}

Probiotics, also known as direct-fed microbials, are live microbial feed supplements which beneficially affect the host animal by improving its intestinal microbial balance (Fuller, 1989). They have been reported to improve feed consumption, feed efficiency, health and metabolism of the host animal (Cheeke, 1991). The total collection of these probiotics, other gut microflora, their genetic elements or genomic materials and their interactive environment or the gastrointestinal tract of the host is termed the "microbiome". Currently efforts are underway to understand the microbiome and elucidate the mode of action of both probiotics and prebiotics due to a great interest in these gut microbiota and their health promoting properties and enhancement of performance of humans and monogastric animals. The scientific basis for the modes of action of probiotics and prebiotics is, therefore, beginning to emerge. According to report of Quigley (2012) a number of human disease states may benefit from the use of probiotics; these include diarrheal illnesses, inflammatory bowel diseases, certain infectious disorders, and irritable bowel syndrome. Prebiotics promote the growth of "good" bacteria, primarily through competitive exclusion resulting in a variety of health benefits. Probiotics have also been reported to: (1) improve feed intake and digestion and production performance (Nahashon et al., 1994a, 1994b, 1994c, 1996), (2) maintain a beneficial microbial population by competitive exclusion and antagonism (Fuller, 1989), and (3) alter bacterial metabolism (Cole et al., 1987; Jin et al., 1997). Nahashon et al (1994a) evaluated the phytase activity in lactobacilli probiotics and the role in the retention of phosphorus and calcium as well as egg production performance of Single Comb White Leghorn laying chickens. They reported phytase activity in the direct-fed microbial and that supplementation of the corn-soy based diets with the probiotics to a $0.25 \%$ available phosphorus diet improved phosphorus retention and layer performance.

Prebiotics are defined as non-digestible food ingredients that beneficially affect the host, selectively stimulating their growth or activity, or both of one or a limited number of bacteria in the colon and thus improve gut health (Gibson and Roberfroid, 1995). They are shortchain-fructo-oligosaccharides (sc-FOS) which consist of glucose linked to two, three or four fructose units. They are not absorbed in the small intestine but they undergo complete fermentation in the colon by colonic flora (Gibson and Roberfroid, 1995). They benefit humans and monogastric animals by: (1) releasing volatile fatty acids which are absorbed in the large intestine and contribute to the animal's energy supply; (2) enhance intestinal absorption of nitrogen, calcium, magnesium, iron, zinc and copper in rats (Ducros et al., 2005); (3) increase the number and/or activity of bifidobacteria and lactic acid bacteria (Hedin et al., 2007); and (4) since they are non-digestible, they provide surface for attachment by pathogenic bacteria and therefore facilitate the excretion of these pathogenic microorganisms.

According to Bouhnik et al. (1994) and Gibson and Roberfroid, (1995), fructooligosaccharides such as inulin, oligofructose, and other short-chain fructooligosaccharides can be fermented by beneficial bacteria such as bifidobacteria and lactobacilli and in turn control or 
reduce the growth of harmful bacteria such as Clostridium perfringens through competitive exclusion. The bifidobacteria and lactobacilli are generally classified as beneficial bacteria (Gibson and Wang, 1994; Flickinger et al., 2003). Although the mode of action of several of these oligosaccharides are still obscure, Biggs et al. (2007, pointed out that even low concentrations $(4 \mathrm{~g} / \mathrm{kg})$ of an indigestible oligosaccharide can be fed to monogastric animals with no deleterious effects on metabolizable energy and amino acid digestibility. The benefit of utilizing oligosaccharides in soy-based diets of monogastric animals are due to the ability of these oligosaccharide to pass through to the hindgut of the monogastric animals intact and to be fermented by beneficial bacteria that are stimulated to grow and produce compounds that are beneficial to the host. These beneficial bacteria are also able to prevent the growth of bacteria such as Escherichia coli and Clostridium perfringens that can be harmful to the host through competitive exclusion (Gibson and Roberfroid, 1995). Biggs and Parsons (2007) reported an increase in the digestibility of a few amino acids was by some oligosaccharides in cecectomized roosters.

\subsection{Amino acids and vitamin supplementation}

Soybean is an excellent source of protein and vegetable oil for human and animal nutrition due to its balanced amino acid profile. According to Berry et al. (1962), methionine is the most limiting amino acid followed by lysine, and threonine. The level of supplementation of the amino acids lysine, methionine, threonine and glycine was evaluated (Waguespack et al., 2009). Feed efficiency decreased significantly in broilers fed diets supplemented with more than $0.3 \%$ L-Lysine but not in birds fed diets containing $0.25 \%$ L-Lysine. It was also observed that up to $0.25 \%$ L-Lysine could be added to corn-soy diets of broilers supplemented with methionine, threonine and glycine. Waguespack et al. (2009) also reported that arginine and valine were equally limiting after methionine, threonine and glycine in the diets containing $0.25 \%$ L-Lysine.

Earlier reports (Douglass and Persons, 2000) demonstrated a significant improvement in feed efficiency by methionine and Lysine supplementation in broilers diets. Studies have shown that excess heating by extrusion cooking or autoclaving of soybean during oil extraction can decrease lysine availability, hence requiring supplementation of this and other amino acids in soybean meal-based diets (Persons et al., 1992). It has also been further established that supplementation of raw soybean meal with methionine is an effective way of eliminating the potential nutritional deficiencies in both the raw and heated soybean meals. Due to the fact that raw soybean contains protein of low quality, supplementation of pig raw soy-based diets with cysteine and the B-complex vitamins exhibited significant improvement in performance (Peterson et al., 1941). Evaluating the effect of supplementation of turkey diets with dL-tocopheryl acetate, Sell et al. (1997) reported that feeding soybean based diets containing 6-20 IU tocopheryl acetate/kg improved performance of male turkeys from 1-day of age to market age. 


\subsection{Heat treatment and autoclaving}

Heat treatment is a common procedure in soybean processing during extraction of oil and the inactivation of antinutritional factors such as trypsin inhibitors. The processing inactivates these protease inhibitors, although there has to be a balance in conditions of heat inactivation since excessive heating could also destroy other essential nutrients. Kwok et al. (1993) demonstrated that excess heat in the inactivation of protease inhibitors of soybean may increases Maillard reactions between the amino group of amino acids and reducing sugars and as a result decrease the digestibility of energy and amino acids by monogastric animals. Comparing the nutritive value of different heat treated commercial soybean meals, Veltmann et al. (1986) reported that compared to the normal meal, excessively heat-treated soybean meal had lower crude protein which also reflected lower essential and non-essential amino acids, and less trypsin inhibitors. Herkelman et al. (1991) evaluated the effect of heating time and sodium metabisulfite (SMBS) on the nutritional value of full fat soybeans for chicks. They observed that chicks fed the full-fat soybean achieved maximum performance when the soybeans were heated at $121^{\circ} \mathrm{C}$ for $40 \mathrm{~min}$, and the SMBS decreased by one half the heating times required inactivating trypsin inhibitors.

\section{Health benefits of soybean in human nutrition}

\subsection{General overview}

Soybeans which boast rich content of protein (38-40\%) of high quality and with a balanced amino acids profile are widely grown around the world and are the most important world source of edible oil and protein. Besides it's use in livestock feeds and to some extent biofuels, soybean is processed into products that are utilized for human consumption such as soybean oil and fermented soybean products which have long been utilized to prepare healthy human foods worldwide (Kim et al., 1999). Highly purified and oil-free food grade proteins isolates containing as high as $95 \%$ crude protein are commonly utilized in human foods. In the United States, $90 \%$ of the soybean is used for food especially as soybean oil (Smith and Wolf, 1961). In Asia and other parts of the world, soybean and soybean products are routinely utilized in large quantities in various forms of foods such as mature soybean, soybean flour, soybean meal, soybean milk, and also as oriental soybean products such as tofu, natto, miso, shoyu, and sprouts. In the recent past there has been increased focus on soybean as human food because of its health benefits. As a result, considerable research effort has been directed to evaluating the health benefits and increasing the uses of soybean in human foods. Abundant supplies of high protein soybean products and the rapid development of the soybean processing industry has also contributed significantly to the increased use of soybean as human food.

\subsection{Selected components of soybean that confer health benefits}

Soybean and soybean products have been acclaimed to confer health benefits to consumers because they contain substances that have been confirmed to bear health conferring proper- 
ties. These substances include Iron, isoflavones, high content of protein rich in balanced amino acids, the sulfur containing amino acids methionine and cysteine, saponins, phytoestrogens, and the omega-3 fatty acids present in soybean oil. Soybeans are a major source of nonheme iron in diets of humans. Although some of the iron is unavailable for it is in the form of ferritin complexed with phytate, calcium and proteins, iron in soybean is a bioavailable source for human consumption. On the other hand, the benefits of omega-3 long chain fatty acids to heart health are well established (Lemke et al., 2010) and enrichment of soybean oil with these fatty acids has been a sustainable way of increasing tissue concentration of these omega- 3 fatty acids and in reducing the risk of cardiovascular disease.

Soybean also contains nonstarch polysaccharide (NSP) hydrolysis products of soybean meal. These nonstarch polysaccharide hydrolysis products of soybean meal are beneficial in maintaining fluid balance during Enterotoxigeic Escherichia Coli (ETEC) infection and controlling ETEC-induced diarrhea in piglets. Soybean fermented with R. oligosporus produce antibacterial compounds that are active against some gram-positive microorganisms. The material can be extracted with water from soybeans fermented by R. oligosporus. Genistein and other soybean isoflavones slow the growth of blood vessels to tumors, another action that makes it popular as a cancer fighter.

\subsection{Disease prevention properties of soybean}

\subsubsection{Cholesterol}

Soybean, a popular source of protein for both humans and other monogastric animals due to its protein content and quality, especially the balance of amino acids, is an invaluable source of oil which contains fatty acids known to be effective in prevention of cardiovascular disease. The US Food and Drug Administration (1999) indicated that soybean proteins were responsible for prevention of cardiovascular disease. According to Lovatti et al. (1996) the soybean 7S or $\beta$-conglycinin has also been implicated in the upregulation of liver high-affinity LDL receptors. This protein was also shown to reduce plasma triglycerines in humans and rats (Aoyama et al., 2001). Later studies (Duranti et al., 2004) evaluated the effect of soybean 7S globulin subunits on the upregulation of LDL receptors. They reported that it lowered the expression of $\beta$-VLDL receptors induced by soybeam subunit. The oral admoinistration of soybean 7S globulin and the $\alpha$-subunit significantly reduced plasma cholesterol and tryglycerides of hypercholesterolemic rats (Duranti et al., 2004). On the other hand, feeding soybean ( $25 \mathrm{~g} /$ day) was associated with lower total cholesterol concentrations in individuals with initial cholesterol concentratons of greater than $5.7 \mathrm{mmol} / \mathrm{L}$ (Bakhit et al., 1994). Later studies (Carroll, 1991) demonstrated that soybean protein lowered blood lipids in humans and experimental animals. Sirtori et al. (1985) also demonstrated that a 50\% substitution of animal protein with soybean protein significantly reduced blood cholesterol concentrations of humans with type II familial hypercholesterolemia.

Soybean fiber has also been reported to reduce blood lipids whereas comsumption of cookies containing $25 \mathrm{~g}$ soybean cotyledon fiber was associated with a significant reduction in total plasma LDL cholesterol in hypercholesterolemic patients (Lo et al., 1986). Various 
mechanisms of reduction of cholesterol in humans and other monogastric animals have been proposed. These include the direct effect of soybean peptides which may modulate the endocrine regulation of catabolism and/or reduction in cholesterol biosynthesis (Bakhit et al., 1994). Most recently, Cho et al. (2007) suggest that soy peptides can effectively stimulate LDL-R transcription in the human liver cell line and reduce blood cholesterol level. They proposed several mechanism and component of the cholesterol lowering activity of soybean which include blockage of bile acid and/or cholesterol absorption, inhibition of cholesterol synthesis, and stimulation of low-density lipoprotein receptor (LDL-R) transcription. Similar observations were reported earlier by Beynen et al. (1986) that hypocholesterolemic effect of dietary soybean protein was caused primarily by its influence on the heterohepatic circulation of bile acids and cholesterol.

\subsubsection{Cancer}

Soybean is a rich protein source for humans and monogastric animals and contains about $0.2-1.5 \mathrm{mg} / \mathrm{g}$ of the isoflavones daidzein and genistin, and their glycones daidzein and genistkein (Wang and Murphy, 1994). These isoflavones have been proposed to possess anticarsinogenic properties which may be associated with their ability to serve as antioxidants which prevent fat rancidity, $\beta$-carotene bleaching and glutathione peroxidase activity (Hendrich et al., 1994), antiestrogens, and inhibiting the estrogen synthetase preadipocyte aromatase in humans (Aldercreutz et al., 1993). Adlercreutz et al. (1991) suggested that the low breast cancer incidence in Japanese women may be attributed to their consumption of feeds rich in soybean, a source of isoflavones. These isoflavones in soybean such as genistein confer anticarcinogenic effect primarily by inhibiting estrogen binding to the estrogen receptors; the soy isoflavones compete for estrogen receptors.

Xu et al. (1995) also hypothesized that soybean isoflavones possess anticarsinogenic properties. They anaerobically incubated soybean isoflavones with human feces and observed that intestinal half life daidzein and genistein were as little as 7.5 and $3.3 \mathrm{hrs}$, respectively. Hence the bioavailability of these isoflavones was depended on the ability of gut microflora to degrade these compounds. They attributed the cancer protective effects of the isoflavones to also the isoflavone metabolites such as methyl p-hydroxyphenylacetate, a monophenolic compound of both exogenous flavonoids and tyrosine which are inhibitors of hormone-dependent neoplastic cell proliferation. This compound has high affinity for nuclear type II binding site which is involved in cell growth regulation by estrogenic hormones (Xu et al., 1995).

In his report, Messina (1999) stated that soybean isoflavones may reduce the risk of prostrate cancer in men and breast cancer in women. The anti-cancer properties in soybean are attributed to the isoflavone genistein which influence signal transduction and the potential role in preventing and treating cancer. McMichael-Phillips et al. (1998) observed a significant enhancement of DNA synthesis by breast cells taken from biopsies of normal breast tissue from women with benign and malignant breast disease when these women were fed soybean for about two weeks. On other studies (Jing et al., 1993) reported that daidzein, one of the two primary isoflavones in soybean exhibited anti-cancer effects by inhibiting the growth of HL-60 cells implanted into the subrenal capsules of mice. The anticancer effects of 
the isoflavone genistein may be attributed to its antioxidant properties and its ability to inhibit several enzymes that are involved in signal transduction (Wei et al., 1993) including tyrosine protein kinase (Akiyama et al., 1987), ribosomal $S 6$ kinase (Linassier et al., 1990), Map kinase (Thoburn et al., 1994), the inhibition of the activity of DNA topoisomerase and increasing the concentration of transforming growth factor $\beta$ (TGF $\beta$ ) as reported by Benson and Colletta (1995).

The interest in soybean and soybean products has been driven by its potential health benefits, especially in prevention of various forms of cancer by the soybean isoflavones genistein, deidzein and glycitein. In more recent studies, Su et al. (2000) reported that isoflavones played a protective role against bladder cancer cells. They also observed that both genistein and combined isoflavones exhibited significant tumor seppressing effects. According to Messina and Barnes (1991), increased soybean consumption reduced the risk of breast, colon and breast cancer for people living in Asia as opposed to people living in the United States and Western Europe. A comprehensive review of the interelationship between diet and cancer by The World Cancer Research Fund (1997) revealed that vegetable intake decreased the risk of colon cancer. The increased consumption of soybean and soybean products have also been reported to reduce the risk of colon cancer in some human and animal populations.

While examining the ability of dietary soybean components to inhibit the growth of prostate cancer, Zhou et al. (1999) reported that dietary soybean products inhibited experimental prostrate tumor growth through direct effects in the tumor cells and indirectly through the effect on tumor neurovesculature. Earlier reports (Herbert et al., 1998) showed that increased consumptio of soybean products contributed to reduction in prostrate cancer risk. Phytochemicals in soybean have been reported to posses anticarcinogenic properties (Messina et al., 1994). Zhou et al. (1999) further observed that soybean isoflavones and phytochemicals inhibited LNCaP cell proliferation, blocked cell cycle progression and enhanced DNA fragmentation which is a marker for opoptosis or programmed cell death. Datta et al., (1997) reported that soybean is capable of oxidizing benzo (a) pyrene-7, 8-dihydrodiol and 2-aminofluorine which are known to cause developmental toxicity or transplacental carcinogenicity in mammals. In other studies, Wei et al., (1995) cited evidence that genistein's antioxidant properties and antiproliferative effects may be responsible for its anticarcinogenic effects. Therefore, high content of genistein in soybean and its high bioavailability increases soybean's potential for prevention of various forms of cancer.

Soybean saponins have also been cited as potential contributors to the health promoting properties of soybean and soybean products. Saponins are chemical structures consisting of triterpenoidal or steroidal aglycones with various carbohydrates moieties in plants. Saponins are excellent emulsifyers since they bear both hydrophilic and hydrophobic regions and they tend to inhibit colon tumor cell proliferation in vitro. Various saponins have demonstrated antimutagenic and anticarcinogenic effecta against cell lines. More recent studies (Ellington et al., 2005) suggested that the B-group soyasaponins may be colon cancer suppressive component os soybean serving as potential chemopreventative phytochemical. Therefore, soybean and soybean products should be explored further for their potential in prevention and treatment of the various forms of cancer. 


\subsubsection{Osteoporosis}

Osteoporosis is a degenerative thinning of the bones that is associated with decreasing estrogen levels which is a common problem with aging, especially in women. According to Ikenda et al. (2006), soybeans and soybean products which contain large amounts of menaquinone-7 (vitamin K2) may help prevent the development of osteoporosis. Soybeans have also generated interest in connection with osteoporosis because they contain a phytoestrogens called isoflavones, which are believed to have potential as substitute for estrogen without its adverse side effects. Intake of Natto, an ancient Japanese food of fermented soybeans, was reported to bear properties that were preventative of postmenopausal bone loss through the effects of menaquinone-7 or bioavailable isoflavones which were more abundant in natto than in other soybean products (Ikenda et al., 2006). Heaney (1996) described vitamin $\mathrm{K}$ functionally as a cofactor of $\gamma$-carboxylase enzyme which mediates the conversion of undercarboxylated osteocalcin to carboxylated osteocalcin by transforming the glutamyl residue of osteocalcin into carboxyglutamic acid residue. The carboxyglutamic acids have high affinity for calcium ions in hydroxyapatite and regulate the growth of these crystals in bone formation. Therefore there is sufficient evidence to suggest that fermented soybean products can effectively maintain bone stiffness (Katsuyama et al., 2002) by increasing serum levels of menaquinone-7 and $\gamma$-carboxylated osteocalcin (Kaneki et al., 2001) as well as maintaining bone mineral density.

Soybean and soybean-based diets for human contain naturally occurring bioactive compounds known as phytochemicals that have been cited to confer long-term health benefits (Setchell, 1998). These phytoestrogens primarily occur as glycosides bearing a weak estrogen-like activity which allows them to bind to the estrogen receptor (Miksicek, 1994) and therefore are of great significance as remedy where estrogen levels decline due to old age. These isoflavones can serve as alternative to estrogen therapy in the treatment of existing low bone mass or osteoporosis. They present potential naturally occuring alternative to hormone or drug therapy (estrogen) that would minimize bone loss in menopausal women.

In other studies, Picherit et al. (2001) assessed the dose-dependent effect of daily soybean isoflavones consumption in reversing bone loss in adult ovariectomized rats. They reported that in adult ovariectomized rats, daily soybean isoflavone consumption decreased bone turnover but did not reverse established osteopenia. In earlier studies using a rat model, Arjmandi et al. (1996) evaluated the potential for soybean protein isolate to prevent bone loss induced by ovarian hormone deficiency. They reported an increase in femoral and vertebral bone densities in rats that were fed soybean diets possibly due to the presence of isoflavones in soybean.

\section{Nutritional benefits of soybean in other monogastric animals}

\subsection{Poultry}

Soybean meal is the primary protein source in corn-soy based poultry rations. It is fed to poultry as soybean meal and is primarily the by-product of soybean oil extraction; it's the 
ground defatted flakes. Various studies have been conducted to evaluate methods of enhancing the acceptability of soybean and the enhancement of its nutritional value in poultry feeding. For instance, a study was conducted to evaluate the effect of extruding or expander processing prior to solvent extraction on the nutritional value of soybean meal (SBM) for broiler chicks. The results of this study indicate that pre-solvent processing method (expander or non-expander) had no significant effect on the nutritional value of SBM for broiler chicks. Both Methionine and Lysine supplementation increased feed efficiency (Douglas and Persons, 2000). Several other studies (Coca-Sinova et al. 2008; Dilger et al. 2004; Opapeju et al. 2006) have evaluated various methods of enhancing the digestibility of individual amino acids and protein of soybean meal.

The guinea fowl is classified as poultry and although its production is not popular as chickens, it is gradually gaining popularity and acceptance as alternative meat to chicken. It is also gradually finding its share of the global market for poultry and poultry products. Lacking however, is estimates for nutrient requirements of the guinea fowl. Recent efforts have focused on evaluating the growth pattern of the guinea fowl (Nahashon et al. 2010) and their nutrient requirements (Nahashon et al. 2009, 2010, 2011). The soybean meal has been utilized extensively as the sole protein source for the guinea fowl providing accurate estimate for the nutrient requirements for both the Pearl Grey and French varieties of the guinea fowl.

\subsection{Swine}

Soybean meal and soybean products have also been used extensively in swine production because of its relatively high concentration of protein (44 to 48\%) and its excellent profile of highly digestible amino acids. Soy protein provides most amino acids that are deficient in most cereal grains commonly fed as energy sources in swine production. However, as opposed to feeding animal source proteins, when raw soybean is fed to young pigs as the primary protein source, dramatic slowdown in body weight gains were reported even with supplementation of amino acids such as methionine and cysteine (Peterson et al., 1942). The animal source proteins tend to exhibit higher digestibility than plant source proteins such as soybean and therefore better suited for nursery pigs (Kim et al., 2009; Gottlob et al., 2006). The low digestibility of raw soybean by young pigs is therefore attributed to the low nutritive value of the raw soybean protein. Due to the high cost of feeding and also the antinutritional factors in raw soybean, there have been attempts to minimize the amount of soybean in swine rations and also to improve its digestibility. The digestibility of the amino acids of soybean by swine has also been researched quite extensively (Smiricky-Tjardes et al. 2002; Grala et al., 1998; NRC 1998).

The supplementations of raw soybean with the amino acids threonine and the B- complex vitamins have been reported to enhance growth in young pigs. Also fermented soybean meals, soybean meals with enzyme supplements and extruded soybean meals have been used extensively in swine diets and they tend to improve performance especially of young pigs (Kim et al., 2006). Kim et al. (2009) reported an increase in crude protein concentration from 50.3 to $55.3 \%$ by fermentation of soybean meal with A. oryzae without affecting the balance of limiting amino acids for pigs. Bruce et al. (2006) evaluated the inclusion of soybean 
(SB) processing byproducts such as gums, oil, and soapstock into soybean meal. Addition of these processing by-products significantly reduced the nutritive value of the resultant meal. Smiricky-Tjardes et al. (2003) evaluated other approaches such as the addition of galactooligosaccharides on ileal nutrient digestibility to enhance and expand the utilization of soybean in swine production.

\subsection{Aquatic life}

The feeding value of soybean as a rich protein source has also been extended to aquaculture. The high protein level makes soybean meal a key ingredient for aquaculture feeds since soybean meal is considerably less expensive than traditionally used marine animal meals. However, soybeans not contain complete amino acid profiles and usually are deficient in the essential amino acids lysine and methionine. Therefore, other protein sources should be used in combination with soybean to overcome the deficiencies. Soybean meal and genetically modified soybean products have also been employed in aquaculture (Hammond et al. 1995). Naylora et al. (2009) points to the importance of fish oils and fishmeal as a protein source in food animal production and also the extensive use of soybean and soybean products as protein supplements in aquaculture feeds.

\subsection{Companion animals}

The term "companion animals" refers to the entire spectrum of animal species which are considered as 'pets' such as cats, dogs, fish, rabbits, rodents, cage birds, and even non-indigenous species. Large animals such as horses, as well as small ruminants such as the goats and sheep have also been classified as companion animals as well because they contribute to human companionship; they have an important role to play in our society. The companion animal industry is rapidly growing sector of the global economy and so is the need for provision of adequate nutritional regimens for optimum growth, production and reproduction. Relatively few data are available on the nutrient digestibilities of plant-based protein sources by companion animals.

Plant source proteins such as soybean and soybean products are predominantly used in diets of companion animals. Soybeans are an essential part of Plant-based protein sources and are generally less variable in chemical composition than animal-based protein sources especially in nutrients such as calcium and phosphorus. The effects of including selected soybean protein sources in dog diets on nutrient digestion at the ileum and in the total tract, as well as on fecal characteristics, were evaluated (Clapper et al. 2001). Apparent amino acid digestibility at the terminal ileum, excluding methionine, threonine, alanine, and glycine, were higher $(\mathrm{P}<0.01)$ for soybean protein-containing diets when compared with diets containing other sources of protein.

The effects of soybean hulls containing varying ratios of insoluble: soluble (I: S) fiber on nutrient digestibility and fecal characteristics of dogs were evaluated (Burkhalter et al., 2001). Ileal digestibility of dry matter by dogs fed the soybean hulls treatments responded quadratically $(P<0.05)$ to I: $\mathrm{S}$ fiber diets, with digestibility coefficients decreasing as the I:S ap- 
proached 3.2. In other studies (Tso and Ling, 1930) reported that the blood cholesterol value of rabbits is slightly higher in animals fed the soybeans diets than in controls. However, differences in cholesterol levels between rabbits fed on cooked and raw soybeans were not statistically significant. Also the blood of rabbits fed exclusively on water-soaked raw soybeans showed an increase in uric acid, urea nitrogen, inorganic phosphorus and cholesterol. After extending this study to feeding cooked soybeans, there are no demonstrable changes in the blood composition of rabbits whether they were fed cooked or raw soybeans.

The optimum concentration of a mixture of soybean hulls and defatted grape seed meal (SHDG) for rabbits was evaluated (Necodemus et al. 2007). They observed that SHDG could be included up to $26.7 \%$ in diets for fattening rabbits and lactating does that meet ADL and particle size requirements. In another study, Angora goat doelings (average BW $22.1 \mathrm{~kg}$ ) were used to examine the effects of dietary crude protein level and degradability on mohair fiber production (Sahlu et al. 1992). They reported that plasma glucose was elevated 2 hours after feeding in the goats fed conventional, solvent-extracted soybean meal, whereas glucagon concentrations were greater at 0 and $4 \mathrm{~h}$ in the group fed expelled, heat-treated soybean meal.

\section{Author details}

Samuel N. Nahashon ${ }^{1^{*}}$ and Agnes K. Kilonzo-Nthenge ${ }^{2^{*}}$

*Address all correspondence to: snahashon@tnstate.edu

1 Department of Agricultural Sciences, Tennessee State University, Nashville, TN, USA

2 Department of Family and Consumer Sciences, Tennessee State University, Nashville, TN, USA

\section{References}

[1] Aljmandi, B. H., Elekel, L., Hollis, B. W., Amin, D., Stacewicz-Sapuntzakis, M., Guo, P., \& Kukreja, S. C. (1996). Dietary soybean protein prevents bone loss in an ovarectomized rat model of osteoperosos. J. Nutr., 126, 161-167.

[2] Adeola, O., \& Cowieson, A. J. (2011). Board-invited review: Opportunities and challenges in using exogenous enzymes to improve nonruminant animal production. $J$. Anim. Sci, 89, 3189-3218.

[3] Adachi, M., Kanamori, J., Masuda, T., Yagasaki, K., Kitamura, K., Mikami, B., \& Utsumi, S. (2003). Crystal structure of soybean 11S globulin: Glycinin A3B4 homohexamer. Proceedings of the National Academy of Sciences, USA,, 100, 7395-7400. 
[4] Adler-Nissen, J. (1978). Enzymatic hydrolysis of soy protein for nutritional fortification of low pH food. Annals of Nutrition and Alimentation, 32, 205-216.

[5] Adlercreutz, H., Bannwart, C., Wahala, K., Makela, T., Brunow, G., Hase, T., Arosemena, P. J., Kellis, J. T., Jr , , \& Vickey, E. L. (1993). Inhibition of human alromatase by mammalian lignans and isoflavonoids phytoestrogens. J. Steroid Biochem. Mol. Biol., 44, 147-153.

[6] Adlercreutz, H., Honjo, S., Higashi, A., Fotsis, T., Hamalainem, E., Hasegawa, T., \& Okada, H. (1991). Urinary excretion of lignans and isoflavonoid phytoestrogens in Japanese men and women consuming a traditional Japanese diet. Am. J. Clin. Nutr., 54, 1093-1100.

[7] Akiyama, T., Ishida, J., Nakagawa, S., et al. (1987). . Genistein, a specific inhibitor of tyrosine specific protein kinases. J. Biol. Chem. ., 262, 5592-5595.

[8] Asada, K., Tanaka, K., \& Kasai, Z. (1969). Formation of phytic acid in cereal grains. Ann NY Acad Sci , 165, 801-814.

[9] Applegate, T. J., Webel, D. M., \& Lei, X. G. (2003). Efficacy of a phytase derived from Escherichia coli and expressed in yeast on phosphorus utilization and bone mineralization in turkey poults. Poult. Sci., 82, 1726-1732.

[10] Angkanaporn, K., Ravindran, V., \& Bryden, W. L. (1996). Additivity of apparent and true ileal amino acid digestibilities in soybean meal, sunflower meal, and meat and bone meal for broilers. Poultry Science, 75(9), 1098-1103.

[11] Augspurger, N. R., \& Baker, D. H. (2004). High dietary phytase levels maximize phytate-phosphorus utilization but do not affect protein utilization in chicks fed phosphorusor amino acid-deficient diets. J. Anim. Sci., 82, 1100-1107.

[12] Barbazan, M. (2004). Liquid swine manure as a phosphorous source for corn-soybean rotation. Thesis. Iowa State University, Ames, Iowa.

[13] Beilinson, V., Chen, Z., Shoemaker, C., Fischer, L., Goldberg, B., \& Nielsen, C. (2002). Genomic organization of glycinin genes in soybean. Theoretical and Applied Genetics, $104,1132-1140$.

[14] Buhr, T., Sato, S., Ebrahim, F., Xing, A., Zhou, Y., Mathiesen, M., et al. (2002). Ribozyme termination of RNA transcripts down-regulate seed fatty acid genes in transgenic soybean. The Plant Journal, 3, 155-63.

[15] Beynen, A. C., Van Der Meer, R., West, C. E., Cugano, M., \& Kritchevsky, D. (1986). Possible mechanisms underlying he differential cholesterolemic effects of dietary casein and soy protein. In:, Nutritional effects on Cholesterol Metabolism, (Beynen, A. C, ed),, 29-45, Transmondial, Voorthuizen, The Netherlands.

[16] Benson, J. R., \& Colletta, A. A. (1995). Transforming growth factor $\beta$. prospects for cancer prevention and treatment. Clin. Immunother, 4, 249-258. 
[17] Biggs, P. \& Pearsons, C. M. (2007). The Effects of Several Oligosaccharides on True Amino Acid Digestibility and True Metabolizable Energy in Cecectomized and Conventional Roosters. Poultry Science, 86, 1161-1165.

[18] Braden, C. R. (2006). Salmonella enterica serotype enteritidis and eggs: a national epidemic in the United States. Clin. Infect. Dis., 43, 512-517.

[19] Barth, Christian A., Bruta Lãoehding, Martin Schmitz \& Hans Hagemeister. (1993). Soybean trypsin inhibitor(s) reduce absorption of exogenous and increase loss of endogenous protein. J. Nutr., 123, 2195-2200.

[20] Beynen, A. C., Winnubst, E. N. W., \& West, C. E. (1983). The effect of replacement of dietary soybean protein by casein on the fecal excretion of neutral steroids in rabbits. Z. Theraphysiol. Tierrer. naehr. Futtermittelkd., 49, 43-49.

[21] Berry, T. H., Becker, D. E., Rasmussen, O. G., Jensen, A. H., \& Norton, H. W. (1962). The Limiting Amino Acids in Soybean Protein. J ANIM SCI, 21(3).

[22] Burkhalter, T. M., Merchen, N. R., Bauer, L. L., Murray, S. M., Patil, A. R., Brent, J. L., Jr , , Fahey, G. C., \& Jr 200, . (2001). The Ratio of Insoluble to Soluble Fiber Components in Soybean Hulls Affects Ileal and Total-Tract Nutrient Digestibilities and Fecal Characteristics of Dogs. J. Nutr., 131, 1978-1985.

[23] Biggs, P., Parsons, C. M., \& Fahey, G. C. (2007). The Effects of Several Oligosaccharides on Growth Performance, Nutrient Digestibilities, and Cecal Microbial Populations in Young Chicks. Poultry Science, 86, 2327-2336.

[24] Bouhnik, Y., Flourie', B., Ouarne, F., Riottot, M., Bisetti, N., Bornet, F., \& Rambaud, J. (1994). Effects of prolonged ingestion of fructo-oligosaccharides on colonic bifidobacteria, fecal enzymes and bile acids in humans. Gastroenterology, 106, A598, (Abstr.).

[25] Balloun, S. L., \& 198, . (1980). Soybean meal processing. In: K.C. Lepley (Ed) Soybean Meal in Poultry. The Ovid Bell press, Inc., Fulton, Missouri. , 6-12.

[26] Bhakit, R., Klein, B. P., Essex-Sorlie, D., Ham, J. O., Erdman, J. W., \& Porter, S. M. (1994). Intake of $25 \mathrm{~g}$ of soybean protein with or wothout soybean fiber alters plasma lipids in men with elevated cholesterol concentrations. J. Nutr., 124, 213-222.

[27] Carrol, K. K. (1991). Review of clinical studies on cholesterol lowering response to soy protein. J. Am. Diet. Assoc., 91, 820-827.

[28] Cahoon, E. B., Carlson, T. J., Ripp, K. G., Schweiger, B. J., Cook, G. A., Hall, S. E., \& Kinney, A. J. (1999). Biosynthetic origin of comnjugated double bonds: production of fatty acids components of high-value drying oils in transgenic soybean embryos. Proceedings of the National Academy of Sciences, USA,, 22, 12935-12940.

[29] Clemente, T. E., \& Cahoon, E. B. (2009). Soybean Oil: Genetic Approaches for Modification of Functionality and Total Content. Plant Physiology, 151, 1030-1040. 
[30] Cook, D. R. (1998). The effect of dietary soybean isoflavones on the rate and efficiency of growth and carcass muscle content in pigs and rats. Ph.D. Dissertation. Iowa State Univ.,.

[31] Cowieson, A. J. (2005). Factors that affect the nutritional value of maize for broilers. Anim. Feed Sci. Technol., 119, 293-305.

[32] Protease inhibitors and carcinogenesis: a review. Cancer Invest , (1996). , 14, 597-608.

[33] Clapper, G. M. C. M., Grieshop, N. R., Merchen, J. C., Russett, J. L., Brent Jr, , Fahey, G. C., \& Jr , . (2001). Ileal and total tract nutrient digestibilities and fecal characteristics of dogs as affected by soybean protein inclusion in dry, extruded diets. J ANIM SCI., 79, 1523-1532.

[34] Clemente, Tom E., \& Edgar, B. Cahoon. (2009). Soybean Oil: Genetic Approaches for Modification of Functionality and Total Content. Plant Physiology., 151(3), 1030-40.

[35] Coca-Sinova, A., Valencia,t, D. G., Jimenez-Moreno,t, E., Lazaro,t, R., \& Mateos, G. G. (2008). Apparent Ileal Digestibility of Energy, Nitrogen, and Amino Acids of Soybean Meals of Different Origin in Broilers. Poultry Science, 87, 2613-2623.

[36] Cheryan, M. (1980). Phytic acid interactions in food systems. CRC Crit. Rev. Food Sci. Nutr., 13, 297-335.

[37] Cowieson, A. J., \& Ravindran, V. (2008). Effect of exogenous enzymes in maize-based diets varying in nutrient density for young broilers: Growth performance and digestibility of energy, minerals and amino acids. Br. Poult. Sci., 49, 37-44.

[38] Coon, C. N., Leske, K. L., Akavanichan, O., \& Cheng, T. K. (1990). Effect of oligosaccharide-free soybean meal on true metabolizable energy and fiber digestion in adult roosters. Poult. Sci., 69, 787-793.

[39] Cordle, C. T. . (2004). Soy Protein Allergy: Incidence and Relative Severity 12135 EOF-1219S EOF.

[40] Crump J.A, Griffin P.M, Angulo FJ. (2002). Bacterial contamination of animal feed and itsrelationship to human foodborne illness. Clin Infect Dis, 35, 859-865.

[41] Cheeke, P. R. (1991). Applied Animal Nutrition. AVI Publishing Company, Inc., Wesport, CT.

[42] Cole, C. B., Fuller, R., \& Newport, M. J. (1987). The effect of diluted yogurt on the gut microbiology and growth of piglets. Food Microbiol., 4, 83-85.

[43] Choct, M. (2006). Enzymes for the feed industry: Past, present and future. World's Poult. Sci. J., 62, 5-16.

[44] Cummings, K. J., Gaughan, D. M., Kullman, G. J., Beezhold, D. H., Green, B. J., Blachere, F. M., Bledsoe, T., Kreiss, K., \& Cox-Ganser, J. (2010). Adverse respiratory outcomes associated with occupational exposures at a soy processing plant. ERJ, 36, 1007-1015. 
[45] Datta, K., Sherblom, P. M., \& Kulkarni, A. P. (1997). Co-oxidative metabolism of 4aminobiphenyl by lipoxygenase from soybean and human term placenta. Drug Metab. Desp., 25, 196-205.

[46] Dalluge, J. J., Eliason, E., \& Frazer, S. (2003). Simultaneous identification of soyasaponins and isoflavones and quantification of soyasaponin $\mathrm{Bb}$ in soy products using liquid chromatography/electrospray ionization-mass spectrometry. Journal of Agricultural and Food Chemistry, 51, 3520-3524.

[47] Drewnowski, A. (2001). The science and complexity of bitter taste. Nutrition Review," 59, 163-169.

[48] Duranti, M., Lovati, M. R., Dani, V., Barbiroli, A., Scarafoni, A., Castinglion, S., Ponzone, C., \& Morazzoni, P. (2004). The $\alpha$-subunit fro soybean 7S globulin lowers plasma lipids and upregulates liver $\beta$-VLDL receptors in rats fed a hypercholesterolemic diet. J. Nutr., 134, 1334-1339.

[49] Dauglas, M. W., \& Parsons, C. M. (2000). Effect of presolvent extraction processing method on the nutritional value of soybean meal for chicks. Poult. Sci., 79, 1623-1626.

[50] Dilger, R. N., Sanders, J. S., Ragland, D., \& Adiola, O. (2004). Digestibility of nitrogen and amino acids in soybean meal with added soyhulls. J. Anim. Sci., 82, 715-724.

[51] Dixon, R. A. (2004). Phytoestrogens. Annu. Rev. Plant Biol. , 55, 225-261.

[52] Davis, Hancock. D. D., Rice, D. H., Call, D. R., Di Giacomo, R., Samadpour, M., et al. (2003). Feedstuffs as a vehicle of cattle exposure to Escherichia coli O157:H7 and Salmonella enterica. Vet Microbiol, 95, 199-210.

[53] De Rham, O., \& Jost, T. (1979). Phytate-protein interactions in soybean extracts and low-phytate soy protein products. J. Food Sci., 44, 596-600.

[54] Doerge, DR, \& Sheehan, DM. (2002). Goitrogenic and estrogenic activity of soy isoflavones. Environ Health Perspect., 110(3), 349-53.

[55] Divi, RL, Chang, HC, \& Doerge, DR. (1997). Anti-thyroid isoflavones from soybean: isolation, characterization, and mechanisms of action. Biochem Pharmacol., 54(10), 1087-96.

[56] Dubey, R. K., Rosselli, M., Imthurn, B., Keller, P. J., \& Jackson, E. K. (2000). Vascular effects of environmental oestrogens: implications for reproductive and vascular health. Hum Reprod Update, 4, 351-363.

[57] Du, Pont. H. L. (2007). The growing threat of foodborne bacterial enteropathogens of animal origin. Clinical Infectious Diseases, 45, 1353-1361.

[58] Ducros, V., Arnaud, J., Tahiri, M., Coudray, C., Bornet, F., Bouteloup-Demange, C., Brouns, F., Rayssiguier, Y., \& Roussel, A. M. (2005). Influence of short-chain fructooligosaccharides (sc-FOS) on absorption of $\mathrm{Cu}, \mathrm{Zn}$, and Se in healthy postmenopausal women. J. American College of Nutr., 24(1), 30-37. 
[59] DeRouchey J.M, Tokach, M.D., Nelsen J. L, Goodband, R. D., Dritz, S. S., Woodworth, J. C., \& James B. W. (2002). Comparison of spray-dried blood meal and blood cells in diets for nursery pigs. J. Anim. Sci., 80, 2879 EOF-86 EOF.

[60] Elias, R., De Meo, M., Vidal-Ollivier, E., et al. (1990). Antimutagenic activity of some saponins isolated from Calendula officinalis L., C arvensis L., and Hedra helix L.". Mutagenesis, 5, 327-331.

[61] Ellington, A. A., Barlow, M., \& Singletary, K. W. (2005). Induction of macroautophagy in human colon cancer cells by soybean B-group triterpenoid saponins. Carciniogenesis, 26, 159-167.

[62] Eliot, M., Herman, Ricki. M., Helm, Rudolf., Jung, , \& Anthony, J. Kinney. (2003). Genetic Modification Removes an Immunodominant Allergen from Soybean. (1), 1-36.

[63] Fort, P., Moses, N., \& Fasano, M. (1990). Breast and soy-formula feedings in early infancy and the prevalence of autoimmune thyroid disease in children. J Am Coll Nutr, 9, 164-167.

[64] Frankel, E. N. (1987). Secondary products of lipid oxidation. Chemistry and Physics of Lipids, 44, 73-85.

[65] Friedman, M., \& Brandon, D. L. (2001). Nutritional and health benefits of soy proteins. Journal of Agricultural and Food Chemistry, 49, 1069-1086.

[66] Flickinger, E. A., Schreijen, E. M. W. C., Patil, A. R., Hussein, H. S., Grieshop, C. M., Merchen, N. R., Fahey, G. C., \& Jr , . (2003). Nutrient digestibilities, microbial populations, and protein catabolites as affected by fructan supplementation of dog diets. $J$. Anim. Sci., 81, 2008-2018.

[67] Fuller, R. (1989). Probiotics in man and animals. A review. J. Appl. Bacteriol., 66, 365-378.

[68] Gudbrandsen, O. A., Wergedahl, H., Mork, S., Liaset, B., Espe, M., \& Berge, R. K. (2006). Dietary soya protein concentrate enriched with isoflavones reduced fatty liver, increased hepatic fatty acid oxidation and decreased the hepatic mRNA level of VLDL receptor in obese Zucker rats. Br. J. Nutr., 96, 249-257.

[69] Green, S., Bertrand, S. L., Duron, M. J., \& Maillard, R. (1987). Digestibility of amino acids in soyabean, sunflower and groundnut meals, determined with intact and caecectomised cockerels. British Poultry Science, 28(4), 643-652.

[70] Garcia, M. C., Torre, M., Marina, M. L., \& Laborda, F. (1997). Composition and characterization of soyabean and related products. Critical Reviews in Food Science and Nutrition, 37, 361-391.

[71] Grala, W., Verstegen, M. A., Jansman, A. J. M., Huisman, J., \& Van Leeusen, P. (1998). Ileal apparent protein and amino acid digestibilitiesand endogenous nitrogenlosses in pigs fedsoybean and rapeseed products. J. Anim. Sci., 76, 557-568. 
[72] Gertler, A., Birk, Y., \& Bondi, A. (1967). A comparative study of the nutritional and physiological significance of pure soybean trypsin inhibitors and of ethanol-extracted soybean meals in chicks and rats. J. Nutr., 91, 358-370.

[73] Goldflus, F., Ceccantini, M., \& Santos, W. (2006). Amino acid content of soybean samples collected in different brazilian states-Harvest 2003/2004. Braz. J. Poult. Sci., 8, 105-111.

[74] Gibson, G. R., \& Wang, X. (1994). Inhibitory effects of bifidobacteria on other colonic bacteria. J. Appl. Bacteriol., 77, 412-420.

[75] Gibson, G. R., \& Roberfroid, M. B. (1995). Dietary modulationof the human colonic microbiota-Introducing the concept of prebiotics. J. Nutr., 125, 1401-1412.

[76] Ghadge, V. N., Upase, B. T., \& Patil, P. V. (2009). Effect of replacing groundnut cake by soybean meal on performance of broilers. Veterinary World, 2(5), 183-184.

[77] Gaylord, B. S., Heeger, A. J., \& Bazan G. C. (2003). DNA hybridization detection with water-soluble conjugated polymers and chromophore-labeled single-stranded DNA. J. Am. Chem. Soc., 125, 896 EOF-900 EOF.

[78] Grieshop, C. M., Catzere, C. T., Clapper, G. M., Flickinger, E. A., Bauer, L. L., Frazier, R. L., \& Fahey, G. C. Jr. (2003). Chemical and nutritional characteristics of United States soybeans and soybean meals. J. Agric. Food Chem., 51, 7684-7691.

[79] Grieshop, C. M., \& Fahey, G. R. (2001). Comparison of quality characteristics of soybeans from Brazil, China and the United States. J. Agric Food Chem, 49, 2669-2673.

[80] Halina, 1., Nathan, S., \& Ephrain, K. (1966). Soybean hemagglutinin, a plant glycoprotein. I. Isolation of a glycopeptide.

[81] Hong Y. H., Wang, T. C., Huang, C. J., Cheng, W. Y., \& Lin, B. F. (2008). Soy isoflavones supplementation alleviates disease severity in autoimmune-prone MRL-lpr/lpr mice. Lupus, 17, 814-821.

[82] Heaney, R. P., Weaver, C. M., \& Fitzsimmons, M. L. (1991). Soybean phytate content: effect on calciumabsorption. Am. J. Clin Nutr, 53, 745-747.

[83] Herman, E. M., Ricki, M., Helm, R., Anthony, J., \& Kinney, J. (2003). Genetic Modification Removes an Immunodominant Allergen from Soybean. Plant Physiology, 132(1).

[84] Harris, L. J., Farber, J. N., Beuchat, L. R., Parish, M. E., Suslow, T. V., Garrett, E. H., \& Busta, F. F. (2003). Outbreaks associated with fresh produce: incidence, growth, and survival of pathogens in fresh and fresh-cut produce. Comprehensive Reviews in Food Science and Food Safety Supplement, 79-141.

[85] Herman, E. M. (2003). Genetically modified soybeans and food allergies. Journal of Experimental Botany, 54(386), 1317-1319. 
[86] Hwang, David. 1., Wen-kuang, Yang., Donald, E., \& Foard, . (1978). Rapid Release of Protease Inhibitors from Soybeans. Plant Physiol., 61, 30-34.

[87] Hayakawa, K., Mitzutani, J., Wada, K., Masai, T., Yoshihara, I., \& Mitsuoka, T. (1990). Effects of soybean oligosaccharides on human fecal flora. Microbiol. Ecol. Health Dis., 3, 293-303.

[88] Harada, J. J., Barker, S. J., \& Goldberg, R. B. (1989). Soybean beta-conglycinin genes are clustered in several DNA regions and are regulated by transcriptional and posttranscriptional processes. The Plant Cell, 1, 415-425.

[89] Herman, E. M., Helm, R. M., Jung, R., \& Kinney, A. J. (2003). Genetic modification removes an immunodominant allergen from soybean. Plant Physiology , 132, 36-43.

[90] Hildebrand, D. F. (1989). Lipoxygenase. Physiologia Plantarum, 76, 249-253.

[91] Hitz, W. D., Carlson, T. J., Kerr, P. S., \& Sebastian, S. A. (2002). Biochemical and molecular characterization of a mutation that confers a decreased raffinosaccharide and phytic acid phenotype on soybean seeds. Plant Physiology, 128, 650-660.

[92] Hedin, C., et al. (2007). Evidence for the use of probiotics and prebiotics in inflammatory bowel disease: a review of clinical trials. Proc Nutr Soc., 66(3), 307-15.

[93] Hendrich, S., Lee, K. W., Xu, X., Wang, H. J., \& Murphy, P. A. (1994). Defining food components as new nutrients. J. Nutr., 124, 1789S EOF-1792S EOF.

[94] Herkelman, K. L., Cromwel, G. L., \& Stahly, T. (1991). Effect of heating time and sodium metabisulfite on the nutritional value of full-fat soybeans for chicks. J. Anim. Sci., 69, 4477-4486.

[95] Hoaglund CM, VM Thomas, MK Peterson, and RW Knott. (1992). Effects of supplemental protein source and metabolizable energy intake on nutritional status in pregnant ewes. J. Anim. Sci., 70, 273 EOF-80 EOF.

[96] Hammond, B. C. J. L., Vicini, C. F., Hartnell, M. W., Naylor, C. D., Knight, E. H., Robinson, R. L., Fuchs, , \& Padgette, S. R. (1995). The feeding value of soybeans fed to rats, chickens, catfish and dairy cattle is not altered by genetic incorporation of glyphosate tolerance. J. Nutr., 126, 3-717.

[97] Heaney, R. P. (1996). Nutrition and the risk of osteoporosis. In: Marcus R Fieldman D, Kelsey J. L., editors., Osteoperosis, Academic press: San Diego, CA; 483-509.

[98] Holle, D. G. (1995). Amino Acids. Ratite Feeds and Feeding, 1-2, 58-59.

[99] Herkelman, K. L., Cromwell, G. L., \& Stahly, T. S. (1991). Effect of heating time and sodium metabisulfite on the nutritional value of full-fat soybean for chicks. J. Anim. Sci., 69, 4477-4486.

[100] Honig, D. H., Elaine, M., Hockridge, Robert. M., Gould, , Joseph, J., \& Rackis, . (1983). Determination of Cyanide in Soybeans and Soybean Products. Journal of Agricultural E Food Chemistry, 272-275. 
[101] Irish, G. G., \& Balnave, D. (1993). Non-starch polysaccharides and broiler performance on diets containing soyabean meal as the sole protein concentrate. Australian Journal of Agricultural Research, 44(7), 1483-1499.

[102] Ikuomola, D. S., \& Eniola, K. I. T. (2010). Microbiological Quality and Public Health Risk Associated with Beske: Fried Soybean Snack, Retailed in Ikeji-Arakeji, Osun State, Nigeria. Nigeria Journal of Microbiology ,, 24(1), 2114-2118.

[103] Irish, G. G., \& Balnave, D. (1993). Non-starch polysaccharides and broiler performance on diets containing soyabean meal as the sole protein concentrate. Aust. J. Agric. Res., 44, 1483-1499.

[104] Izabelawoclawek-potocka, Mamadou. M., Bah, Anna., Korzekwa, Mariusz. K., Piskula, Wiesławwiczkowski., Andrzej, Depta., \& Skarzynski, D. J. (2005). Soybean-Derived Phytoestrogens Regulate Prostaglandin Secretion in Endometrium During Cattle Estrous Cycle and Early Pregnancy. Experimental biology and Med, 230, 189-199.

[105] Irish, G. G., \& Balnave, D. (1993). Non-starch polysaccharides and broiler performance on diets containing soyabean meal as the sole protein concentrate. Australian Journal of Agricultural Research, 44(7), 1483-1499.

[106] Jin, L. Z., Ho, Y. W., Abdullah, N., \& , S. Jalaludin(1997). Probiotics in poultry: modes of action. World's Poultry Sci. J. , 53, 353-368.

[107] Jung, W., Yu, O., Lau, S. M., O'Keefe, D. P., Odell, J., Fader, G., \& Mc Gonigle, B. (2000). Identification and expression of isoflavone synthase, the key enzyme for biosynthesis of isoflavones in legumes. Nature Biotechnology, 18, 208-212.

[108] Sherill, J. D., Morgan, Sparks., M.D., John, M. M., Kemppainen, B. W., Bartol, F. F., Morrison, E. E., \& Akingbemi, B. T. (2010). Developmental Exposures of Male Rats to Soy Isoflavones Impact Leydig Cell Differentiation. Biology of Reproduction, 83, 488-501.

[109] Jing, Y., Nakaya, K., \& Han, R. (1993). Differentiation of promyelocytic leukemia cells HL-60 induced by daidzein in vitro and in vivo. Anti Cancer Res., 13, 1049S-1054S.

[110] Kaneki, M., Hedjes, S. J., Hosol, T., Fijiwara, S., Lyons, A., Crean, S. J., Ishida, N., Nakagawa, M., \& Takechi, M. (2001). Japanese fermented soybean food as the major determinant of the largegeographic difference in circulating levels of vitamin $\mathrm{k} 2$ : possible implications of hip fracture risk. Nutrition, 17, 315-321.

[111] Kunihiko, U., Chieko, T. \& Isao, K. (2010). Inactivation of Bacillus subtilis spores in soybean milk by radio-frequencyflash heating. Journal of Food Engineering, 100, 622-626.

[112] Katsuki, Y., Yasuda, K., Ueda, K, \& Naoi, Y. (1978). Annu. Rep. Tokyo Metrop. Res. Lab. Public Health, 29, 261.

[113] Knaus, W. F, Beermann, D. H., Robinson, T. F., Fox, D. G., \& Finnerty, K. D. (1998). Effects of a dietary mixture of meat and bone meal, feather meal, blood meal, and 
fish meal on nitrogen utilization in finishing Holstein steers. J. Anim. Sci., 76, 1481 EOF-7 EOF.

[114] Kats, L. J., Nelssen J. L., Tokach, M. D., Goodband, R. D., Hansen, J. A., \& Laurin, J. L. (1994). The effect of spray-dried porcine plasma on growth performance in the earlyweaned pig. J. Anim. Sci., 72, 2075 EOF-81 EOF.

[115] Karr-Lilienthal, L. K., Mershem, N. R., Grieshop, C. M., Flahaven, M. A., Mahan, D. C., Watts, N. D., Fahey, G. C., \& Jr , . (2004). Ileal amino acid digestibilities by pigs fed soybean meals from five major soybean producing countries. J. Anim Sci, 82, 3198-3209.

[116] Karr-Lilienthal, L. K., Grienshop, C. M., Spears, J. K., Fahey, G. C., \& Jr , . (2005). Amino acid, carbohydrate, and fat composition of soybean meals prepared at 55 commercial U.S. soybean processing plants. J. Agric. Food Chem., 53, 2146-2150.

[117] Karr-Lilienthal, L. K., Grieshop, C. N., Merchen, N. R., Mahan, D. C., Fahey, G. C., \& $\mathrm{Jr}$, . (2004). Chemical composition and protein quality comparisons of soybeans and soybean meals from five leading soybean-producing countries. J. Agric. Food Chem., 52, 6193-6199.

[118] Katsuyama, H., Ideguchi, S., Fukunaga, M., Saijoh, K., \& Sunami, S. (2002). Usual dietary intake of fermented soybeans (natto) is associated with bone mineral density in premenopausal women. J. Nutr. Sci. Vitaminol (Tokyo)., 48, 207-215.

[119] Kalinski, A., Melroy, D. L., Dwivedi, R. S., \& Herman, E. M. (1992). A soybean vacuolar protein (p34) related to thiol proteases is synthesized as a glycoprotein precursor during seed maturation. The Journal of Biological Chemistry, 267, 12068-12076.

[120] Kelley, D. S., \& Erikson, K. L. (2003). Modulation of body composition and immune cell functions by conjugated linoleic acid in humans and animal models:benefits vs. risks. Lipids, 38, 377-390.

[121] Kinney, A. J. (1996). Development of genetically engineered soybean oils for food applications. Journal of Food Lipids, 3, 273-292.

[122] Kinney, A. J., \& Knowlton, S. (1998). Designer oils: the high oleic acid soybean. In S. Roller \& S. Harlander (Eds.),, Genetic modification in the food industry: A strategy for food quality improvement, 193-213, London: Blackie.

[123] Kinney, A. J., \& Fader, G. M. (2002). U.S. Patent [6], Washington, DC: US Patent and Trademark Office.

[124] Kinsella, J. E. (1979). Functional properties of soy proteins. Journal of the American Oil Chemists Society, 56, 242-258.

[125] Kitamura, K. (1995). Genetic improvement of nutrional and food processing quality in soybean. Japan Agricultural Research Quarterly, 29, 1-8. 
[126] Kitts, D. D., \& Weiler, K. (2003). Bioactive proteins and peptides from food sources. Applications of bioprocesses used in isolation and recovery. Current Pharmaceutical Design, 9, 1309-1323.

[127] Knapp, H. R., Salem, N., Jr , , \& Cunnane, S. (2003). Dietary fats and health. Proceedings of the $5^{\text {th }}$ Congress of the International Society for the Study of Fatty Acids and Lipids, $38,297-496$.

[128] Kunitz, M. (1946). Crystalline soybean trypsin inhibitor. J. Gen. Phygiol.,, 9, 149-154.

[129] Kwok, K. C., Qin, W. H., Tsang, J. C. 1993. Heat Inactivation of Trypsin Inhibitors in Soymilk at Ultra-High Temperatures. J. Food Science 58:859-862.

[130] Liu, N., Liu, G. H., Li, F. D., Sands, J. S., Zhang, S., Zheng, A. J., \& Ru, Y. J. (2007). Efficacy of Phytases on Egg Produ. ction and Nutrient Digestibility in Layers Fed Reduced Phosphorus Diets. Poultry Science, 86, 2337-2342.

[131] Lim, H. S., Namkung, H., \& Paik, I. K. (2003). Effects of phytase supplementation on the performance, egg quality, and phosphorous excretion of laying hens fed different levels of dietary calcium and nonphytate phosphorous. Poult. Sci., 82, 92-99.

[132] Lenehan, N. A., De Rouchey, J. M., Goodband, R. D., Tokach, M. D., Dritz, S. S., Nelssen, J. L., Groesbeck, C. N., \& Lawrence, K. R. (2007). Evaluation of soy protein concentrates in nursery pig diets. J. Anim. Sci., 85, 3013-3021.

[133] Lemke, S. L., Vicini, J. L., Su, H., Goldtein, D. A., Nemeth, M. A., Krul, E. S., \& Harris, W. S. (2010). Dietary intake of steriodonic acid-enriched soybean oil increases the omega-3 index:randomized, double-blind clinical study of afficacy and safety. J. Clin. Nutr., 92, 766-775.

[134] Liener, I. E. (1953). Soyin, a toxic protein from the soybean. J. Nutrition, 49, 527.

[135] Liener, I. E. (1994). Implications of antinutritional components in soybean foods. Crit. Rev. Food Sci. Nutr., 34, 31-67.

[136] Liu, Jiang-Gong and Lin Tser-KeShun,. (2008). Survival of Listeria monocytogenes inoculated in retail soymilk products. Food Control,, 19(2008), 862-867.

[137] Linassier, C., Pierr, M., Le Pacco-B, J., \& Pierre, J. (1990). Mechanisms of action in NIH-3T3 cells of genistein, an inhibitor of EGF receptor tyrosine kinase activity. Biochem Pharmacol, 39, 187-193.

[138] Leske, K. L., Jevne, C. J., \& Coon, C. N. (1993). Effect of oligosaccharide additions on nitrogen-corrected truemetabolizable energy of soy protein concentrate. Poult. Sci., 72, 664-668.

[139] Lienei, I. E., \& Kakade, M. L. (1969). Protease inhibitors. In I. E. Liener (Ed.), Toxic Constituents of Plant Foodstuffs., Academic Press, New York.

[140] Liener, I. E. (1981). Factors affecting the nutritional quality of soy products. J. Am. Oil. Chem. Soc., 58, 406-415. 
[141] Liener, L. E., \& Kakade, M. L. (1980). Protease Inhibitors. In: I. E. Liener (Ed), Toxic Constituents of Plant Foodstuffs., 7-71, Academic Press, New York.

[142] Linz, A. L., Xiao, R. J., Ferguson, M., Badger, T. M., \& Simmen, F. A. (2004). Developmental feeding of soy protein isolate to male rats inhibits formation of colonic aberrant crypt foci: Major response differences to azoxymethane (AOM) in SpragueDawley rats from two colonies. FASEB J., 18, A127.

[143] Lovati, M. R., Manzoni, C., Corsini, A., Granata, A., Fumagalli, R., \& Sirtori, C. R. (1996). 7S globulin from soybean is metabolized in human cell cultures by a specific uptake and degradation system. Journal of Nutrition,, 126, 2831-2842.

[144] Lovati, M. R., Manzoni, C., Corsini, A., Granata, A., Fumagalli, R., Sirtori, C., \& , R. (1992). Low density lipoprotein (LDL) receptor activity.

[145] Madden, R. H., Murray, K. A., \& Gilmore, A. (2004). Determination of principal points of product contamination during beef carcass dressing process in Northern Ireland. J. of. Food Prot., 67, 1494-1496.

[146] Foley, S.L., White, D. G., McDermott, P.F., Walker, R.D., \& Messina, M. J. (1999). Legumes and soybean: Overview of their nutritional profiles and health effect. Am. J. Clin. Nutr., 70, 439S-450S.

[147] Mac, Donald. R. S., Guo, J. Y., Copeland, J., Browning, J. D., Jr , , Sleper, D., Rottinghous, G. E., \& Berhow, M. A. (2005). Environmental influences on isoflavones and saponins in soybean and their role in colon cancer. J. Nutr., 135, 1239-1242.

[148] Mc Andrews, G. M., Liebman, M., Cambardella, C. A., \& Richard, T. L. (2006). Residual effects of composted and fresh solid swine (Sus scrofa L.) manure on soybean [Glycine max (L.) Merr.] growth and yield. Agron. J., 98, 873-882.

[149] Montgomery, R. D. (1980). In, Toxic Constituents of Plant Foodstuffs, , 2nd ed.; Liener, I. E., Ed.; Academic Press: New York,.

[150] Maciorowski, K. G., Jones, F. T., Pillai, S. D., \& Ricke, S. C. (2004). Incidence, sources, and control of foodborne Salmonella spp. in poultry feed. World's Poultry Sct. J. , 60, 446-457.

[151] Montazer-Sadegh, R., Ebrahim-Nezhad, Y., \& Maheri-Sis, N. (2008). Replacement of different levels of rapeseed meal with soubean meal on broiler performance. Asian Journal of Animal and Vet. Advances, 3(5), 278-285.

[152] Mc Cue, P., \& Shetty, K. (2004). Health benefits of soy isoflavonoids and strategies for enhancement: A review. Crit. Rev.Food Sci. Nutr., 44, 361-367.

[153] Zimmermann, Michael B. (2009). Iodine Deficiency Endocrine Reviews,, 30(4), 376-408.

[154] Messina, M., \& Redmond, G. (2006). Effects of soy protein and soybean isoflavones on thyroid function in healthy adults and hypothyroid patients: a review of the relevant literature. Thyroid, 16, 249-258. 
[155] Manavalan, L. P., Satish, K., Guttikonda-Son, Lam., Phan, Tran., Henry, T., \& Nguyen, . (2009). Physiological and Molecular Approaches to Improve Drought Resistance in Soybean. Plant Cell Physiol, 50(7), 1260-1276.

[156] Medlock K. L, Branham W. S, \& Sheehan D. M. (1995). Effects of coumestrol and equol on the developing reproductive tract of the rat. Proc Soc Exp Biol Med, 208, 67-71.

[157] Moizzudin, S. (2003). Soybean meal quality in US and World markets. MS. Thesis, IA Iowa State University.

[158] Marty, B. J., Chavez, E. R., \& De Lange, C. F. M. (1994). Recovery of amino acids at the distal ileum for determining apparent and true ileal amino acid digestibilities in growing pigs fed various heat-processed full-fat soybean products. J. Anim. Sci., 72, 2029-2037.

[159] Martin-C, J., \& Valeille, K. (2002). Conjugated linoleic acids: All the same or to everyone its own function? Reproduction Nutrition Development, 42, 525-536.

[160] Maruyama, N., Adachi, M., Takahashi, K., Yagasaki, K., Kohno, M., Takenaka, et., \& al, . (2001). Crystal structures of recombinant and native soybean beta-conglycinin beta homotrimers. European Journal of Biochemistry,, 268, 3595-3604.

[161] Maruyama, N., Mohamed, Salleh. M. R., Takahashi, K., Yagasaki, K., Goto, H., Hontani, N., et al. (2002). Structure-physicochemical function relationships of soybean beta-conglyxcinin heterotrimers. Journal of Agricultural and Food Chemistry,, 50, 4323-4326.

[162] Messina, M., Gardner, C., \& Barnes, S. (2002). Gaining insight into the health effects of soy but a long way still to go. Journal of Nutrition,, 132, 547S EOF-551S EOF.

[163] Mohamed, Salleh. M. R., Maruyama, N., Adachi, M., Hontani, N., Saka, S., Kato, N., et al. (2002). Comparison of protein chemical and physicochemical properties of rapeseed cruciferin with those of soybean glycinin. Journal of Agricultural and Food Chemistry, 42, 525-536.

[164] Messina, M. J., Persky, V., Setchell, K. D., \& Barnes, S. (1994). Soy intake and cancer risk: A review of the in-vitro and vivo data. Nutr. Cancer, 21, 113-131.

[165] Messina, M. J., \& Loprinzi, C. L. (2001). Soy for breast cancer survivors: A critical review of the literature. J. Nutr., 131, 3095S EOF-108S EOF.

[166] Messina, M. J., \& Barnes, S. (1991). The role of soy products in reducing risk of cancer. J. Nutr. Cancer Instit., 83, 541-546.

[167] Messina, M. J. (1999). Legumes and soybeans: Overview of their nutritional profiles and health effects. Am. J. Clin. Nutr., 70, 439S EOF-450S EOF.

[168] Mc Michael-Phillips, D. F., Hardingm, C., \& Morton, M. (1998). Effect of soy protein supplementation on epithelial proliferation in histologically normal human breasts. Am. J. Clin. Nutr. S., 68, 1431S EOF-1435S EOF. 
[169] Milsicek, R. J. (1994). Interaction of naturally occuring nonsteroidal estrogens with expressed recombinant human estrogen receptor. J. Steroid Biochem. Mol. Biol., 49, 153-160.

[170] Nahashon, S. N., \& Kilonzo-Nthenge, A. (2011). Advances in soybean and soybean by-products in monogastric nutrition and health. In, Soybean and Nutrition, Ed. H. A. El-shemy, Intech, Rijeka, Croatia.

[171] Nahashon, S. N., Nakaue, Harry S., \& Mirosh, Larry W. (1996). Performance of Single Comb White Leghorns given a diet supplemented with a live microbial during the growing and egg laying phases. Animal Feed Science and Technology, 57, 25-38.

[172] Nahashon, S. N., Nakaue, H. S., \& Mirosh, L. W. (1994a). Phytase activity, phosphorus and calcium retention and performance of Single Comb White Leghorn layers fed diets containing two levels of available phosphorus and supplemented with directfed microbials. Poultry Science, 73, 1552-1562.

[173] Nahashon, S. N., Nakaue, H. S., \& Mirosh, L. W. (1994b). Production variables and nutrient retention in Single Comb White Leghorn laying pullets fed diets supplemented with direct-fed microbials. Poultry Science, 73, 1699-1711.

[174] Nahashon, S. N., Nakaue, H. S., Snyder, S. P., \& Mirosh, L. W. (1994c). Performance of Single Comb White Leghorn layers fed corn-soybean meal and barley-corn-soybean meal diets supplemented with a direct-fed microbial. Poultry Science, 73, 1712-1723.

[175] Nahashon, S. N., Adefope, N., \& Wright, D. (2011). Effect of floor density on growth performance of Pearl Grey guinea fowl replacement pullets. Poultry Science, 90, 1371-1378.

[176] Nahashon, S. N., Nahashon, A., Akuley, , \& Adefope, N. (2010). Genetic relatedness of Pearl Grey guinea fowl and Single Comb White Leghorn chickens. Journal of Poultry Science, 47, 280-287.

[177] Nahashon, S. N., Aggrey, S. E., Adefope, N. A., Amenyenu, A., \& Wright, D. (2010). Gomperts-Laird model prediction of optimum utilization of crude protein and metabolizable energy by French guinea fowl broilers. Poultry Science, 89, 52-57.

[178] Nahashon, S. N., Adefope, N., Amenyenu, A., \& Wright, D. (2009). The effect of floor density on growth performance and carcass characteristics of French guinea broilers. Poultry Science, 88, 2461-2467.

[179] Tyus, I. I. J., Nahashon, S. N., Adefope, N., \& Wright, D. (2009). Production performance of single comb white leghorn chickens fed growing diets containing blood meal and supplemental blood meal. Journal of Poultry Science, 46, 313-321.

[180] Nagano, T., Fukuda, Y., \& Akasaka, T. (1996). Dynamic viscoelastic study on the gelation properties of beta-conglycinin-rich and glycinin-rich soybean protein isolates. Journal of Agricultural and Food Chemistry, 44, 3484-3488. 
[181] Noordermeer, M. A., Veldink, G. A., \& Vliegenthart, J. F. (2001). Fatty acid hydroperoxide lyase: a plant cytochrome p450 enzyme involved in wound healing and pest resistance. ChemBioChem, 2, 494-504.

[182] Naylora, R. L., Ronald, W., Hardyb, Dominique. P., Bureauc, Alice., Chiua, Matthew., Elliottd, Anthony. P., Farrelle, Ian., Forstere, Delbert. M., Gatlinf,g, Rebecca. J., Goldburgh, Katheline., Huac, , Peter, D., \& Nicholsi, . (2009). Feeding aquaculture in an era of finite resources. PNAS, 106, 36-15103.

[183] Nelson, A. I., Wijeratne, W. B., Yeh, S. W., Wei, T. M., \& Wei, L. S. (1987). Dry extrusion as an aid to mechanically expelling of oil from soybean. J. Am. Oil Chem. Soc., 64, 1341-1347.

[184] NRC. (1998). Nutrient requirements of swine. 10 $0^{\text {th }}$ ed. National Academy Press, Washington, DC.

[185] Nejaty, H., Lacey, M., \& Whitehead, S. A. (2001). Differing effects of endocrine disrupting chemicals on basal and FSH-stimulated progesterone production in rat granulose-luteal cells. Exp Biol Med, 226, 570-576.

[186] Nicodemus, N. J., García, R., Carabaño, , \& De Blas, J. C. (2007). Effect of substitution of a soybean hull and grape seed meal mixture for traditional fiber sources on digestion and performance of growing rabbits and lactating does J. Anim Sci., 85, 181-187.

[187] Opapeju, F. O., , A., Golian, A., Nyachoti, C. M., \& Campbell, L. D. (2006). Amino acid digestibility in dry extruded-expelled soybean meal fed to pigs and poultry. $\mathrm{J}$. Anim. Sci., 84, 1130-1137.

[188] Oakwndull, O. C. (1981). Saponins in Food- A Review. Food Chem, 6, 19-40.

[189] Odunsi, A. A. (2003). Blend of bovine blood and rumen digesta as a replacement for fishmeal and groundnut cake in layer diets. Inter. J. Poult. Sci., 2, 58.

[190] Onwudike, OC. (1981). Effect of various protein sources on egg production in a tropical environment. Trop. Anim. Prod., 6, 249.

[191] Fletciier, a. P., Marks, g. S., Marshall, r. D., \& Neuberger, A. (1963). Biochem J., 8.

[192] Plummer, T. H., , J. R., \& , C. H. W. Hirs.(1963). J. Biol. Chem., , 238, 1396.

[193] Panda, A. K., Rao, S. V. R., Raju, M. V. L. N., \& Bhanja, S. K. (2005). Effect of microbial phytase on production performance of White Leghorn layers fed on a diet low in non-phytate phosphorus. Br. Poult. Sci., 46, 464-469.

[194] Payne, R. L., Bidner, T. D., Southern, L. L., \& Mc Millin, K. W. (2001). Dietary Effects of Soy Isoflavones on Growth and Carcass Traits of Commercial Broilers. Poultry Science, 80, 1201-1207.

[195] Peganova, S., \& Eder, K. (2002). Studies on requirement and excess of isoleucine in laying hens. Poult. Sci., 81, 1714 EOF-21 EOF. 
[196] Powell, S., Bidner, T. D., \& Southern, L. L. (2011). Phytase supplementation improved growth performance and bone characteristics in broilers fed varying levels of dietary calcium 1. Poultry Science, 90, 604-608.

[197] Potter, S. M., Baum, J. A., Teng, H., Stillman, R. J., Shay, N. F., Erdman Jr, , \& , J. W. (1998). Soy protein and isoflavones: Their effects on blood lipids and bone density in postmenopausal women. American Journal of Clinical Nutrition,, 68, 1375S EOF-1379S EOF.

[198] Persons, C. M., Hashimoto, K., Wedekind, K. J., Han, Y., \& Baker, D. H. (1992). Effect of overprocessing on availability of amino acids and energy in soybean meal. Poult. Sci., 71, 133-140.

[199] Paterson, W. J., Hostetler, E. H., \& Shaw, A. O. (1942). Studies in feeding soybean to pigs. J. Anim. Sci., 1, 360.

[200] Palacios, M. F., Easter, R. A., Soltwedel, K. T., Parsons, C. M., Douglas, M. W., Hymowitz, T., \& Pettigrew, J. E. (2004). Effect of soybean variety and processing on growth performance of young chicks and pigs. J. Anim. Sci., 82, 1108-1114.

[201] Peisker, M. (2001). Manufacturing of soy protein concentrate for animal nutrition. 103-107, Feed Manufacturing in the Mediterranean Region, Improving Safety: From Feed to Food. J.Brufau, ed. CIHEAM-IAMZ, Reus, Spain.

[202] Pillai, P. B., O'Connor-Dennie, T., Owens, C. M., \& Emmert, J. L. (2006). Efficacy of an Escherichia coli Phytase in Broilers Fed Adequate or Reduced Phosphorus Diets and Its Effect on Carcass Characteristics. Poultry Science, 85, 1737-1745.

[203] Perilla, N. S., Cruz, M. P., de Belalcazar, F., \& Diaz, G. J. (1997). Effect of temperature of wet extrusion on the nutritional value of full-fat soyabeans for broiler chickens. British Poultry Science, 38(4), 412-416.

[204] Quigley, E. M. M. (2012). Prebiotics and Probiotics Their Role in the Management of Gastrointestinal Disorders in Adults. Nutr. Clin. Pract., 27(2), 195-200.

[205] Rackis, J. J. (1975). Oligosaccharides of food legumes: Alpha-galactosidase activity and the flatus problem. In: A. Jeanes and J.Hodges (ed.) Physiological Effects of Food Carbohydrates., Am. Chem. Soc.,, Washington, DC.

[206] Ravindran, V., Cabahug, S., Ravindran, G., \& Bryden, W. L. (1999). Effects of phytase supplementation, individually and in combination with glycanase, on the nutritive value of wheat and barley. Poult. Sci., 78, 1588-1595.

[207] Rahman, S. M. T., Kinoshita, T., Anai, , \& Takagi, Y. (1999). Genetic relationships between loci for palmitate contents in soybean mutants. J Hered, 90(3), 423 EOF-427 EOF.

[208] Ravindran, V., Morel, P. C., Partridge, G. G., Hruby, M., \& Sands, J. S. (2006). Influence of an Escherichia coli-derived phytase on nutrient utilization in broiler starters fed diets containing varying concentrations of phytic acid. Poult. Sci., 85, 82-89. 
[209] Rhodes, P. J., Fedorka-Cray, S., Simjee, , \& Zhao, S. (2006). Comparison of subtyping methods for differentiating Salmonella enterica serova Typhimurium isolates obtained from animal food sources. J. Clin. Microbiol., 44, 3569-3577.

[210] Roman, S., Temler, Charles. A., Dormono, Eliane., Simon, Brigette., Morel, , \& Christine, Mettraux. (1984). Proteins, Their Hydrolysates and SoybeanTrypsin Inhibitor. J. Nutr., 114, 270-278.

[211] Rangngang M. D, Nelson M. L and S. M Parish. (1997). Ruminal undegradability of blood meal and effects of blood meal on ruminal and postruminal digestion in steers consuming vegetative orchard grass hay. J. Anim. Sci., 75, 2788.

[212] Rosselli, M., Reinhard, K., Imthurn, B., Keller, P. J., \& Dubey, R. K. (2000). Cellular and biochemical mechanisms by which environmental estrogens influence reproductive function. Hum Reprod. Update, 6, 332-350.

[213] Riblett, A. L., Herald, T. J., Schmidt, K. A., \& Tilley, K. A. (2001). Characterization of beta-conglycinin and glycinin soy protein fractions from four selected soybean genotypes. Journal of Agricultural and Food Chemistry, 49, 4983-4989.

[214] Raboy, V., \& Dickinson, D. B. (1984). Effect of phosphorus and zinc nutrition on soybean seed phytic acid and zinc. Plant Physiol., 75, 1094-1098.

[215] Raboy, V., Dickinson, D. B., \& Below, F. E. (1984). Variation in seed total phosphorus, phytic acid, zinc, calcium, magnesium, and protein among lines of Glycine Max and G. Soja. Crop Sci., 24, 431-434.

[216] Rackis, J. J., Wolf, W. J., \& Baker, E. C. (1986). Protease inhibitors in plant foods: Content and inactivation. In: M. Friedman (Ed), Nutritional and Toxicological Significance of Enzyme Inhibitors in Foods, 299-347, Plenum Publishing, New York.

[217] Rackis, J. J. (1972). Biologically active components. In Smith and Circle (Ed.), Soybeans: Chemistry and Technology, Vol. I. The Avi Publ. Co., Inc.,Westport, Conn.

[218] Savage, J. H., et al. (2010). The natural history of soy allergy. J. Allergy Clin. Immunol., $125,683-686$.

[219] Sahlu, T. J. M., Fernandez, C. D., Lu, , \& Manning, R. (1992). Dietary protein level and ruminal degradability for mohair production in Angora goats. J ANIM SCI, 70, 1526-1533.

[220] Sicherer, S. H., \& Sampson, H. A. (2010). Food allergy. J. Allergy Clin. Immunol. S125., 125, S116.

[221] Smiricky, M. R., Grieshop, C. M., Albin, D. M., \& Wubben, J. E. (2002). The influence of soy oligosaccharides on apparent and true ileal amino acid digestibilities and fecal consistency in growing pigs. J. Anim. Sci., 80, 2433-2441.

[222] Sampson, H.A. (2004). Update on food allergy. J Allergy Clin Immunol;, 113, 805-19.

[223] Sicherer, SH. (2002). Food allergy. Lancet, 360, 701-10. 
[224] Sell, J. L., Soto-Salanova, M., Pierre, P., \& Jeffrey, M. (1997). Influence of supplementing corn-soybean diets with vitamin $\mathrm{E}$ on performance and selected physiological traits of male turkeys. Poult. Sci., 76, 1405-1417.

[225] Setchell, K. D. (1998). Phytoestrogens: The niochemistry, physiology, and implications for human health of soy isoflavones. Am. J. Cclin Nutr., 68:, S1333-S1346.

[226] Scheiber, M. D., \& Reber, R. W. (1999). Isoflavones and postmenopausal bone health:A variable alternative to estrogen therapy? Menopause, 6, 233-241.

[227] Slominski, B. A. (1994). Hydrolysis of galactooligosaccharides by commercial preparations of $\alpha$-galactosidase and $\beta$-fructofuranose:Potential for use as dietary additives. J. Sci. Food Agric., 65, 323-330.

[228] Smiricky-Tjardes, M. R., Flickinger, E. A., Grieshop, C. M., Bauer, L. L., Murphy, M. R., \& Fahey, G. C. Jr. (2003). In vitro fermentation characteristics of selected oligosaccharides by swine fecal microflora. J. Anim. Sci., 81, 2505-2514.

[229] Sahn, K. S., Maxwell, C. V., Southern, L. L., \& Buchanan, D. S. (1994). Improved soybean protein sources for early weaned pigs.:Ii. Effect on ileal amino acid digestibility. J. Anim. Sci., 72, 631-637.

[230] Smiricky-Tjardes, M. R., Grieshop, C. M., Flickinger, E. A., Bauer, L. L., \& Fahey, G. C. Jr. (2003). Dietary galactooligosaccharides affect ileal and total0-tract nutrient digestibility, ileal and fecal bacteria concentrations, and ileal fermentative characteristics of growing pigs. J. Anim. Sci., 81, 2535-2545.

[231] Sirtori, C. R., Zucchi-Dentone, C., Sirtori, M., Gatti, E., Descovich, G. C., Gaddi, A., Cattin, L., Da, Col. P. G., Senin, U., Mannarino, E., Avellone, G., Colombo, L., Fragiacomo, C., Noseda, G., \& Lenzi, S. (1985). Cholesterol-lowering and HDL-raising properties of lecithinated soy proteins in tyoe II hyperlipidemia patients. Ann. Nutr. and Metab., 29, 348-357.

[232] Smiricky-Tjardes, M. R., Grieshop, C. M., Albin, D. M., Wubben, J. E., Gabert, V. M., \& Fahey, G. C. Jr. (2002). The influence of soy oligosaccharides on apparent and true ileal amino acid digestibilities and fecal consistency in growing pigs. J. Anim. Sci., 80, 2433-2441.

[233] Smith, A. K., \& Wolf, W. J. (1961). Food uses and properties of soybean protein. I. Food Technology., 15(4).

[234] Schor, A., \& Gagliostro, G. A. (2001). Undegradable protein supplementation to early-lactation dairy cows in grazing conditions. J. Dairy Sci., 84, 1597 EOF-606 EOF.

[235] Seong-Jun, Cho, Juillerat, Marcel A., \& Lee, Cherl-Ho. (2007). Cholesterol Lowering Mechanism of Soybean Protein Hydrolysate. J. Agric. Food Chem., 5, 10599-10604.

[236] Sirtori, C. R., \& Lovati, M. R. (2001). Soy proteins and cardiovascular disease. Current Atherosclerosis Reports, 3, 47-53. 
[237] Soyatech. (2003). New soyfoods market study shows Americans love their soy. Available on the World Wide Web:, http://www.soyatech.com.

[238] Stephan, A., \& Steinhart, H. (1999). Identification of character impact odorants of different soybean lecithins. Journal of Agricultural and Food Chemistry, 47, 2854-2859.

[239] Sindt, M. H., Stock, Klop, R. A., Klopfenstein T. J. \& Shain D. H. (1993). Effect of protein source and grain type on finishing calf performance and ruminal metabolism. $J$. Anim. Sci., 71, 1047 EOF-56 EOF.

[240] Selle, P. H., \& Ravindran, V. (2007). Microbial phytase in poultry nutrition. A review. Anim. Feed Sci. Technol., 135, 1-41.

[241] Smits, C. H. M., \& Annison, G. (1996). Non-starch plant polysaccharides in broiler nutrition-towards a physiologically valid Soy oligosaccharides and pigs 2441proach to their determination. World's Poult. Sci. J., 52, 204-221.

[242] Stott, J. A., Hodgson, J. E., \& Chaney, J. C. (1975). Incidence of Salmonella in animal feed and the effct of pelleting on content of Enterobacteriaceae. J Appl. Bact., 39, 41-46.

[243] Sands, J. S., Ragland, D., Baxter, C., Joern, B. C., Sauber, T. E., \& Adeola, O. (2001). Phosphorus bioavailability, growth performance, and nutrient balance in pigs fed high available phosphorus corn and phytase. J. Anim. Sci., 79, 2134-2142.

[244] Subuh, A. M. H., Moti, M. A., Fritts, C. A., \& Waldroup, P. W. (2002). Use of various ratios of extruded full fat soybean meal and dehulled solvent extracted ;soybean meal in broiler diets. Int. J. Poult. Sci., 1, 9-12.

[245] Southern, L. L., Ponte, J. E., Watkins, K. L., \& Coombs, D. F. (1990). amino acid-supplemented raw soybean diets for finishing swine. J. Anim. Sci., 68, 2387-2393.

[246] Su, S., Yeh, T., Lei, H., \& Chow, N. (2000). The potential for soybean foods as a chemoprevention approach for human urinary tract cancer. Clin. Can. Res., 6, 230-236.

[247] Tyus, J., II., Nahashon S. N., Adefope, N. \& Wright, D. (2008). Growth Performance of Single Comb White Leghorn Chicks Fed Diets Containing Blood Meal Supplemented with Isoleucine. J. Poult. Sci., 45, 31-38.

[248] Tyus, J., II., Nahashon S. N., Adefope, N. \& Wright, D. (2009). Production Performance of Single Comb White Leghorn Chickens Fed Growing Diets Containing Blood Meal and Supplemental Isoleucine. J. Poult. Sci., 46, 313-321.

[249] Tharkur, M., \& Hurburgh, C. R. (2007). Quality of US soybean meal compared to the quality of soybean meal from other origins. J. Am Oil Chem Soc, 84, 835-843.

[250] Thornburn, J., \& Thornburn, T. (1994). The tyrosine kinase inhibitor, geistein, prevents $\alpha$-adrenergic-induced cardiac muscle cell hypertrophy by inhibiting activation of the Ras-MAP kinase signaling pathway. Biochem Biophys Res Commun, 202, 1586-1591. 
[251] Traylor, S. L., Cromwell, G. L., Lindermann, M. D., \& Knabe, D. A. (2001). Effects of level of supplemental phytase on ileal digestibility of amino acids, calcium, and phosphorus in dehulled soybean meal for growing pigs. J. Anim. Sci., 79, 2634-2642.

[252] Tso, E., \& Ling, S. M. (1930). Changes in the Composition of Blood in Rabbits Fed on Raw and Cooked Soybeans. 28(3).

[253] U.S. Soybean Industry: Background Statistics and Information. (2010). United States Department of Agriculture, Economic Research Service. March 28,

[254] U.S. Food and Drug Administration. (1999). Food labeling health claims: Soybean protein and coronary heart disease. Final rule. Fed. Regist., 645, 57699-57733.

[255] Utsumi, S., Katsube, T., Ishige, T., \& Takaiwa, F. (1997). Molecular design of soybean glycinins with enhanced food qualities and development of crops producing such glycinins. Advances in Experimental Medicine and Biology, 415, 1-15.

[256] Vucenik, I., \& Shamsuddin, A. M. (2003). Cancer Inhibition by Inositol Hexaphosphate (IP6) and Inositol:From Laboratory to Clinic. J. Nutr., 133, 3778S-3784S.

[257] Veltmann, Jr., Hansen, B. C., Tanksley, T. D. Jr., Knabe, D., \& Linton, S. L. (1986). Comparison of the nutritive value of different heat-treated commercial soybean meals: utilization by chicks in practical type rations. Poult. Sci., 65, 1561-1570.

[258] Van Kempen, T. A. T. G., Kim, I. B., Jansman, A. J. M., Verstegen, M. W. A., Hancock, J. D., Lee, D. J., Gabert, V. M., Albin, D. M., Fahey, G. C., Jr , , Grieshop, C. M., \& Mahan, D. (2002). Regional and processor variation in the ileal digestible amino acid content of soybean meals measured in growing swine. J. Anim. Sci., 80, 429-439.

[259] Wang, Hwa. L., Doris, I., Ruttle, , \& Hesseltine, C. W. (1969). Antibacterial Compound from a Soybean Product Fermented by Rhizopus oligosporus. Exp Biol Med, 131(2), 579-583.

[260] Wang, H. J., \& Murphy, P. A. (1994). Isoflavon content in commercial soybean foods. J. Agric. Food Chem., 42, 1666-1673.

[261] Wallis, J. G., Watts, J. L., \& Browse, J. (2002). Polyunsaturated fatty acid synthesis: What will they think of next? Trends in Biochemical Sciences, 27, 467-473.

[262] Wansink, B., \& Chan, N. (2001). Relation of soy consumption to nutritional knowledge. Journal of Medical Food,, 4, 145-150.

[263] Weggemans, R. M., \& Trautwein, E. A. (2003). Relation between soy-associated isoflavones and LDL and HDL cholesterol concentrations in humans: A meta-analysis. European Journal of Clinical Nutrition, 57, 940-946.

[264] Waguespack, A. M., Powell, S., Bidner, T. D., Payne, R. L., \& Southern, L. L. (2009). Effect of incremental levels of L-lysine and determination of the limiting amino acids in low crude protein corm-soybean meal diets for broilers. Poult. Sci., 88, 1216-1226. 
[265] Williams, J. E. (1981). Salmonella in poultry feeds a world-widereview. World's Poult. Sci. J., 37, 97-105.

[266] Wu, G., Liu, Z., Bryant, M. M., Roland, D. A., \& Sr , . (2006). Comparison of Natuphos and Phyzyme as phytase sources for commercial layers fed corn-soy diet. Poult. Sci., 85, 64-69.

[267] Wilhelms, K. W., Scanes, C. G., \& Anderson, L. L. (2006). Lack of Estrogenic or Antiestrogenic Actions of Soy Isoflavones in an Avian Model: The Japanese Quail. Poultry Science, 85, 1885-1889.

[268] Wenzel, G. (2008). The Experience of the ZKBS for Risk Assessment of Soybean. Journal fuer Verbraucherschutz und Lebensmittelsicherheit/Journal of Consumer Protection and Food Safety., 3(2), 55-59.

[269] Wei, H., Bowen, R., Cai, Q., Barnes, S., \& Wang, Y. (1995). Antioxidant and antipromotional effects of the soybean isoflavone genistein. Exp. Biol. Med., 208, 124-130.

[270] Wei, H., Wei, L., Frenkel, K., Bowen, R., \& Barnes, S. (1993). Inhibition of tumor promoter-induced hydrogen peroxide formation in vitro and in vivo by genistein. Nutr. Cancer, 20, 1-12.

[271] Woyengo, T. A., Slominski, B. A., \& Jones, R. O. (2010). Growth performance and nutrient utilization of broiler chickens fed diets supplemented with phytase alone or in combination with citric acid and multicarbohydrase. Poultry Science, 89, 2221-2229.

[272] World production of soybean. (2009). Source: FAS/USDA, United States Department of Agriculture, Foreign Agricultural Service-, http://www.fas.usda.gov/psdonline/ psdReport.aspx? hidReportRetrievalName=Table+07\%3a+Soybeans $\% 3 a+$ World + Supply+and+Distribution\&hidReportRetrievalID=706\&hidReportRetrievalTemplateID $=8$ November2009.

[273] Woodworth, J. C., Tokash, M. D., Goodband, R. D., Nelssen, J. L., O'Quinn, P. R., Knabe, D. A., \& Said, N. W. (2001). Apparent ileal digestability of amino acids and the digestible and metabolizable energy content of dry extruded-expelled soybean meal and its effect on growth performance. J. Anim. Sci., 79, 1280-1287.

[274] World Cancer Research Fund and American Institute for Cancer Research. (1997). Food, nutritionand the prevention of cancer. A global perspective. Banta BNook Group, Menasha, WI.

[275] Xiao, C. W. (2008). Health Effects of Soy Protein and Isoflavones in Humans. Journal of Nutrition, 138, 12445-12495.

[276] Xiurong Wang, X., Xiaolong Yan and Hong Liao. (2010). Genetic improvement for phosphorus efficiency in soybean: a radical approach. Ann Bot, 106(1), 215-222.

[277] Xu, Xia. K. S., Harris, H., Wang, P. A., \& Murphy, . (1995). Bioavailability of soybean isoflavones depends upon gut microflora in women. J. Nutr., 125, 2307-2315. 
[278] Wang, X., Nahashon, S. N., Tromondae, K. F., Bohannon-Stewart, A., \& Adefope, A. (2010). An initial map of chromosomal segmental copy number variations in the chicken. BMC Genomics, 11, 351, doi:10.1186/1471-2164-11-351.

[279] Yi, S. Y., Jee-Hyub, Kim., Young-Hee, Joung., Sanghyeob, Lee., Woo-Taek, Kim., Seung, Hun., Yu, , \& Doil, Choi. (2004). The Pepper Transcription Factor CaPF1 Confers Pathogen and Freezing Tolerance in Arabidopsis. Plant Physiology, 136, 2862-2874.

[280] Barbara V., Jiangxin W., \& Huang, Y. (2010). Narrowing Down the Targets: Towards Successful Genetic Engineering of Drought-Tolerant Crops. Mol. Plant, 3(3), 469 EOF-490 EOF.

[281] Yagasaki, K., Takagi, T., Sakai, M., \& Kitamura, K. (1997). Biochemical characterization of soybean protein consisting of different subunits of glycinin. Journal of Agricultural and Food Chemistry, 45, 656-660.

[282] Zimmermann, M. B. (2009). Iodine Deficiency Endocrine Reviews, 30(4), 376-408.

[283] Zhou, J., Gogger, E. T., Tanaka, T., Guo, Y., Blackburn, G. L., \& Clinton, S. K. (1999). Soybean phytochemicals inhibit the growth of transplantable human prostrate carcinoma and tumor angiogenesis in mice. J, Nutr., 129, 1628-1635. 